\title{
Physiological and biochemical effect of neem and other Meliaceae plants secondary metabolites against Lepidopteran insects
}

\section{Sengottayan Senthil-Nathan*}

Division of Biopesticides and Environmental Toxicology, Sri Paramakalyani Centre for Excellence in Environmental Sciences, Manonmaniam Sundaranar University, Tirunelveli, India

\section{Edited by:}

Arash Zibaee, University of Guilan, Iran

\section{Reviewed by:}

Arash Zibaee, University of Guilan, Iran

Maria L. Macedo, Universidade Federal de Mato Grosso do Sul, Brazil

\section{*Correspondence.}

Sengottayan Senthil-Nathan, Division of Biopesticides and Environmental Toxicology, Sri Paramakalyani Centre for Excellence in Environmental Sciences, Manonmaniam Sundaranar

University, Alwarkurichi - 627412 ,

Tirunelveli, India

e-mail: senthil@msuniv.ac.in; senthilkalaidr@hotmail.com
This review described the physiological and biochemical effects of various secondary metabolites from Meliaceae against major Lepidopteran insect pest including, Noctuidae and Pyralidae. The biochemical effect of major Meliaceae secondary metabolites were discussed more in this review. Several enzymes based on food materials have critical roles in nutritional indices (food utilization) of the insect pest population. Several research work has been referred and the effect of Meliaceae secondary metabolites on feeding parameters of insects by demonstrating food consumption, approximate digestibility of consumed food, efficiency of converting the ingested food to body substance, efficiency of converting digested food to body substance and consumption index was reviewed in detail. Further how the digestive enzymes including a-Amylases, $\alpha$ and $\beta$-glucosidases (EC 3.2.1.1), lipases (EC 3.1.1) Proteases, serine, cysteine, and aspartic proteinases affected by the Meliaceae secondary metabolites was reviewed. Further effect of Meliaceae secondary metabolites on detoxifying enzymes have been found to react against botanical insecticides including general esterases (EST), glutathione S-transferase (GST) and phosphatases was reviewed. Alkaline phosphatase (ALP, E.C.3.1.3.1) and acid phosphatase (ACP, E.C.3.1.3.2) are hydrolytic enzymes, which hydrolyze phosphomonoesters under alkaline or acid conditions, respectively. These enzymes were affected by the secondary metabolites treatment. The detailed mechanism of action was further explained in this review. Acethylcholine esterase (AChE) is a key enzyme that terminates nerve impulses by catalyzing the hydrolysis of neurotransmitter, acetylcholine, in the nervous system of various organisms. How the AChE activity was altered by the Meliaceae secondary metabolites reviewed in detail.

Keywords: Meliaceae, secondary metabolites, insect, food consumption, enzyme activity

\section{INTRODUCTION}

Crop protection all over the world relies heavily on the use of synthetic pesticides. In the past, synthetic pesticides have played a major role in crop protection programes and have immensely benefited mankind. The discovery and use of DDT in 1940 and then BHC and subsequent development of the chlorinated cyclodienes marked a major advance in the field of crop protection. These chemicals have made great contributions to plant protection but have also raised a number of ecological and medical problems (Varma and Dubey, 1999). Nevertheless, their indiscriminate use has resulted in the development of resistance by pests (insects, weeds, etc), resurgence and outbreak of new pests, toxicity to non-target organisms and hazardous effects on the environment endangering the sustainability of ecosystems (Jeyasankar and Jesudasan, 2005). It has been estimated that hardly $0.1 \%$ of the agrochemicals used in crop protection reach the target pest leaving the remaining $99.9 \%$ to enter the environment to cause hazards to non-target organisms including humans (Pimentel and Levitan, 1986).
It has been described that more than 2.5 million tons of pesticides are used in agricultural crops protection for every year and the global damage caused by synthetic insecticides reaches more than $\$ 100$ billion annually (USEPA, 2011). The reason behind this amount of cost is the high toxicity and residual properties of pesticides in soil, water, air and crops that affect human and domestic animal health (Carson, 1951). Hence search for the ecofriendly, biodegradable pesticides for management of pest insects have been encouraged to be essential for last five decades.

The ideal insecticide should control target pests adequately and should be target-specific (able to kill the pest insect but not other insects or animals), rapidly degradable, and low in toxicity to humans and other mammals. Two classes of insecticides that exhibit some of these characteristics are the botanical insecticides and the insecticidal soaps. Botanical insecticides, sometimes referred to as "botanicals," are naturally occurring insecticides have been derived from plants. Insecticidal soaps are soaps that have been selected and formulated for their insecticidal action (Weinzierl and Henn, 1991). 
Botanical insecticides have more advantages than synthetic one. The advantages of botanical pesticides mainly depending upon their quick degradation and lack of persistence and bioaccumulation in the eco system, which have been key problems in chemical pesticide use.

Several experiment with botanical pesticides, shows they are degraded in the environment in hours or days. Further literature has clearly shown that use of plant natural products provides low risk when compare with chemical insecticides. The availability and diversity of the secondary metabolites in botanical extracts is renewable source. Also multiple analogs of one compound, is known to increase the efficiency of phytochemcial through synergism, reduce the rate of metabolism of the compounds and prevent the pest resurgence/pesticide resistance (Ascher, 1993; Senthil-Nathan and Kalaivani, 2005, 2006; Ntalli and Menkissoglu-Spiroudi, 2011). Plant community is the most efficient source for natural pesticide. It synthesizes numerous products, many of which have been shown to effect on insect and other harmful organism. Some are highly toxic to a wide range of organisms, including both vertebrates and invertebrates. But majority of plant derived compounds are affecting insects and are comparatively harmless to vertebrates. Such compounds are toxic causing mortality or reduced growth of pest insects. Phytochemcial modes-of-action are more complicated. Most of them are affecting insect performance by repelling an insect and feeding deterrence or oviposition deterrence.

The reviews on plant secondary metabolites/phytochemicals are extensive and have been reviewed by several authors (Arnason et al., 1987; Champagne et al., 1989; Rosenthal and Berenbaum, 1992; Harborne, 1993; Tan and Luo, 2011). But secondary metabolites on insect biochemical mode of action including enzyme activity are still obscure. This review has been mainly attempt to emphasis the biochemical mode of action of Meliaceae secondary metabolites against Lepidopteran insect pests.

\section{BIOLOGICAL ACTIVITIES OF MELIACEAE PLANTS AGAINST LEPIDOPTERAN INSECTS}

The Meliaceae plant family has been given much attention due to its chemical characters called "limonoid" (Connolly, 1983). Meliaceae are distributed in tropical and subtropical regions throughout the world with 50 genera and more than 1400 species (Tan and Luo, 2011). The term limonoids was originated from limonin, the first tetranortriterpenoid acquired from bitter principles of citrus fruits (Devakumar and Sukhdev, 1993; Roy and Saraf, 2006). Current research has pointed out that limonoids are highly oxygenated, modified terpenoids with wide range biological activities especially action against the insects. Not only insecticidal activity it has antibacterial, antifungal, antimalarial, anticancer, antiviral and other clinical activities on humans (Roy and Saraf, 2006). Some reviews related to limonoids from Meliaceae have been presented since 1966. It is noteworthy that some reviews emphasize the well-known azadirachtin (Kraus et al., 1985) and aspects of its chemistry, synthesis (Ley et al., 1993; Sundaram, 1996; Ley, 2005; Devakumar and Kumar, 2008) and bioactivities including antifeedant activity, insecticidal activity and insect-growth-regulating activity (Schmutterer, 1990; Mordue and Blackwell, 1993; Simmonds and Blaney, 1996) as well as its environmental behavior (Sundaram, 1996) and its physiological behavior properties (Mordue and Blackwell, 1993; Mordue, 2004) (Table 1). In addition, the toxicity characteristics of azadirachtin and the mechanisms of its insecticidal action were also reviewed (Champagne et al., 1989; Rembold, 1989). The Indian neem tree (Azadirachta indica A. Juss), one of the important limonoid producing plants from Meliaceae family, has long been recognized as a source of environment-friendly biopesticide. Several constitutions of its leaves and seeds show marked insect control potential and due to their relative selectivity, neem products can be recommended for many Integrated Pest Management (IPM) programs (Schmutterer, 1990).

Most work has focused on azadirachtin and other related compounds (Figures 1A-R) richly from neem seed extracts which act as both potent antifeedants and insect growth regulators. Azadirachtin and its content has antifeedent due to either hydrogenation of $\Delta^{22}$ double bonds or deacetylation caused any change by blocking of hydroxyl group affected the feeding inhibitory activity, while acetylation of azadirachtin caused a decrease in the activity maximum (Roy and Saraf, 2006). Further the stereo chemical structure around hemi acetyl region is important for antifeedent activity. Azadirachtin (Figure 1A) is a Cseco limonoid, which was isolated by Butterworth and Morgan (1968), as an insect feeding deterrent from the seeds of the Indian Neem tree, A. indica contain major limonoids, salannin, meliantriol, nimbin an other than azadirachtin. Azadirachtin affects the insect's reproductive organ, body development and other endocrine events (Mordue and Blackwell, 1993) and does not affect other biocontrol agent. Neem has affected more than 300 insect pests (Mordue and Blackwell, 1993). Further neem products are bio-degradable, mild toxic or no toxic to nontarget organisms, while they are non-toxic toward humans and mammals (Mordue and Blackwell, 1993).

A closely relative of the neem tree is next to important for limonoids availability, Melia azedarach L. Extracts of the seeds are known to contain several limonoids and show excellent insecticidal activity (Srivastava, 1986; Lee et al., 1991; Charleston et al., 2005) but it has not affected biocontrol insects (i.e., predatory mite species (Amblyseii spp.), neem oil was also a feeding deterrent and toxin to Mythimna separata Walker. Apart from azadirachtin $M$. azedarach has the stem bark contain the limonoid toosendanin (Figure 1G) and this is the primary active ingredient of a botanical insecticide recently developed in China (Chiu, 1995). Toosendanin act as a feeding deterrent against Pieris rapae L (Chiu, 1989).

Further bioactive contents are available in few genera include Cedrela, Khaya, Trichilia. Chisocheton Toona and Turaeu (Isman, 1995; Abdelgaleil et al., 2001). Aglaia is another genus in the family Meliaceae and Aglaia was screened against Peridroma saucia Hubner. Seven species of Aglaia were possessed antifeedent activity against $P$. saucia of which were significantly inhibitory to growth (Satasook et al., 1992).

Koul et al. (2004) identified three major compounds, 3-Oacetyl salannol, salannol and salannin from A. indica (Figure 1B). All three compounds were found to affect nutritional indices of Helicoverpa armigera Hübner and Spodoptera litura Fab. Again Koul et al. (2005) found that Aglaia elaeagnoidea (Syn) was 
Table 1 | Biochemical effect of Meliaceae plants secondary metabolites against the Lepidopteran insects.

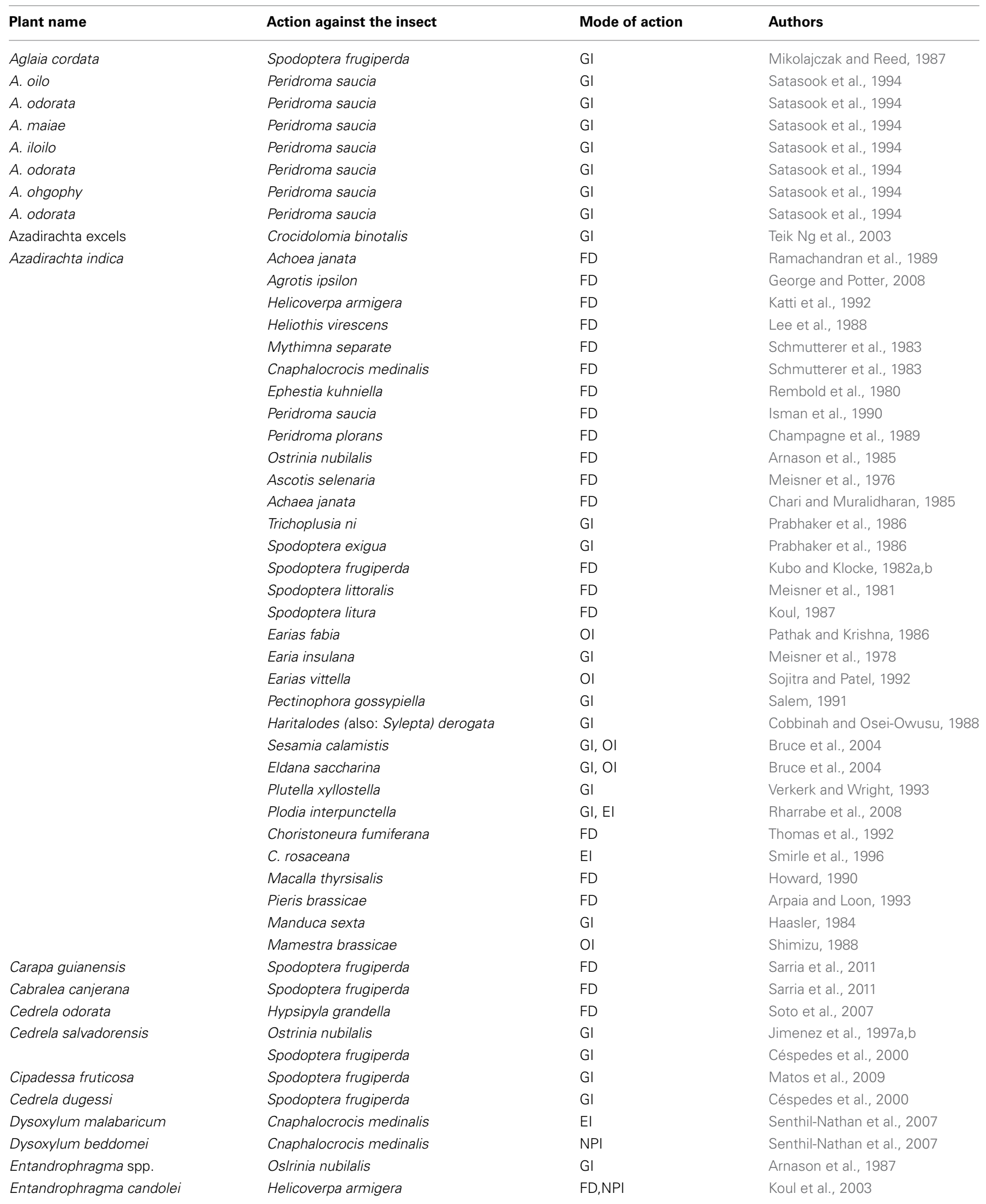


Table 1 | Continued

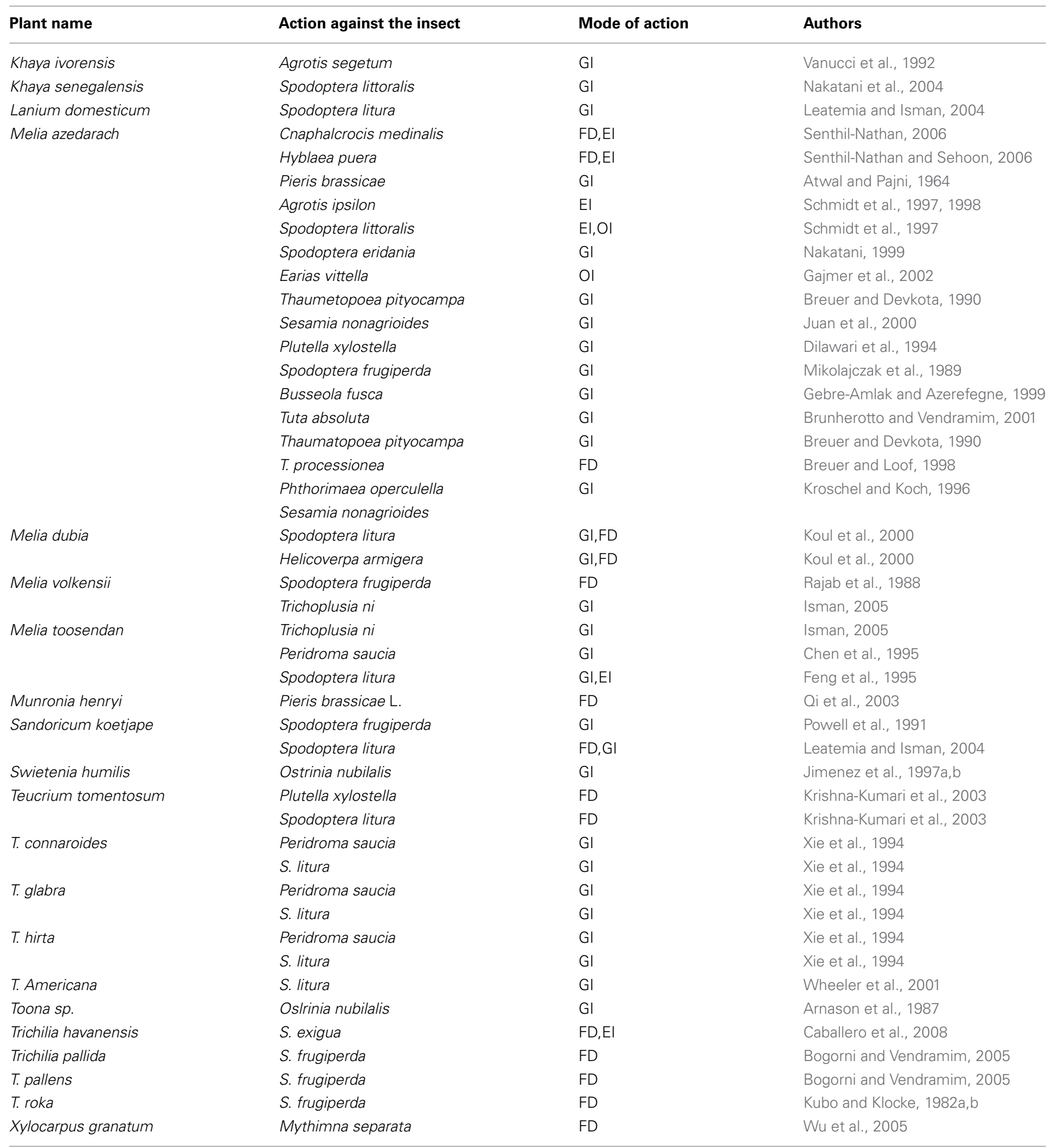

El, Enzyme Inhibition; GI, Growth Inhibition; FD, Feeding Deterrence; NPI, Nutritional Physiology Inhibition; OI, Oviposition Inhibition.

affected nutritional physiology of both $H$. armigera and $S$. litura. The compound aglaroxin A identified from A. elaeagnoidea was potent antifeedent against both Lepidopteran species (Figure 10). The proved that the reduction in growth of the larvae was not entirely due to antifeedent, but partly due to the toxic effects of the aglaroxin A compound. Qi et al. (2003) have been identified compound munroniamide from Munronia henryi and that has proved antifeedent activity against Pieris brassicae L.

Besides the well-known antifeedant activity, azadirachtin also showed strong insect growth regulating activity against many insects (Schmutterer, 1990; Mordue and Blackwell, 1993). Since azadirachtin did not reduce feeding in $P$. brassicae pupae, the 

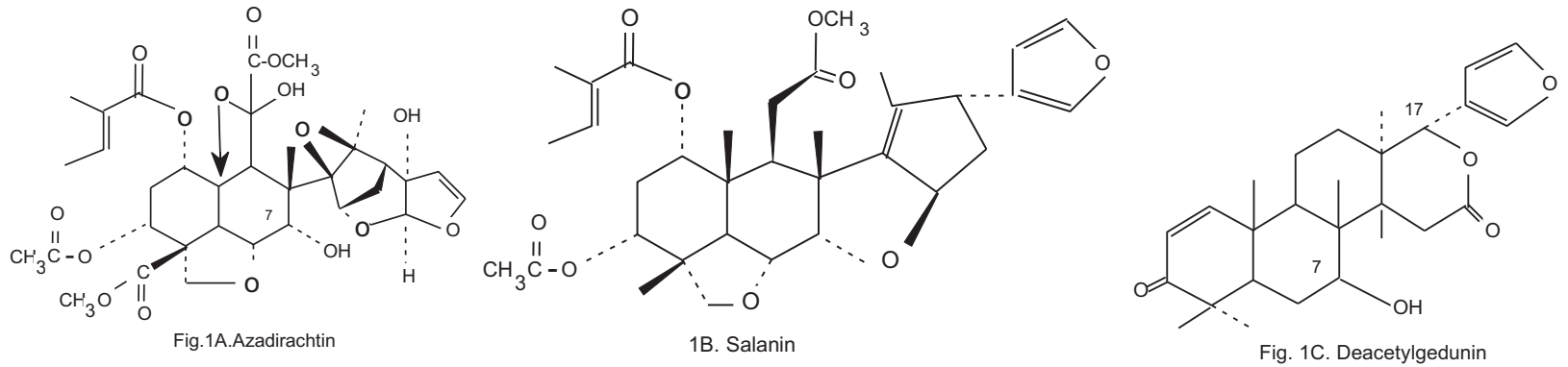

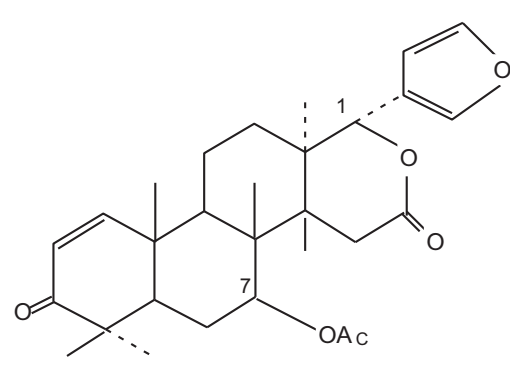

Fig. 1D. Gedunin

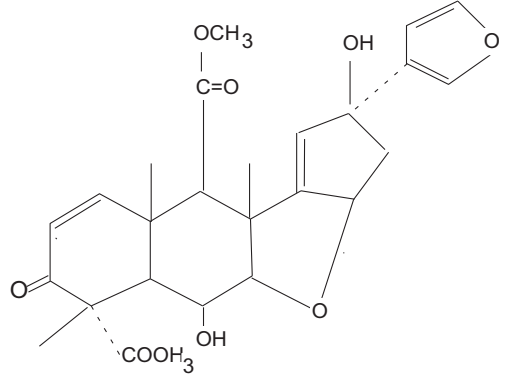

Fig. 1E. 17-Hydroxyazadiradione

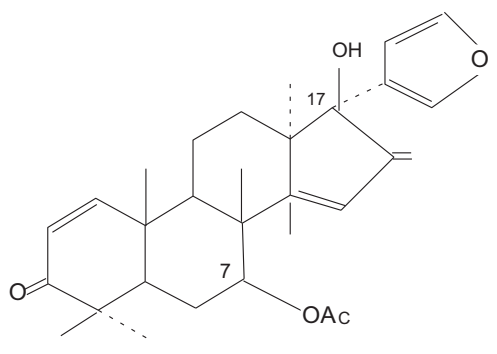

Fig. 1F. Deacetylnimbin

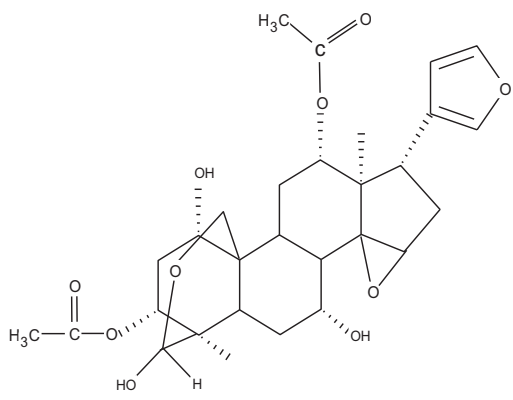

Fig. 1G. Toosendanin.

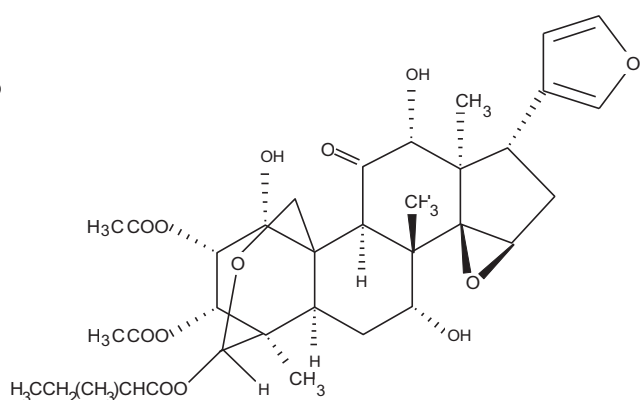

Fig. 1H. Trichilin

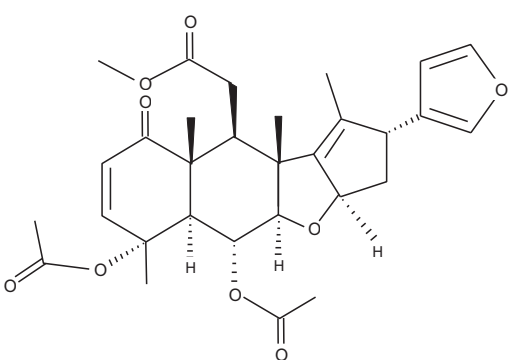

Fig. 11. Nimbin

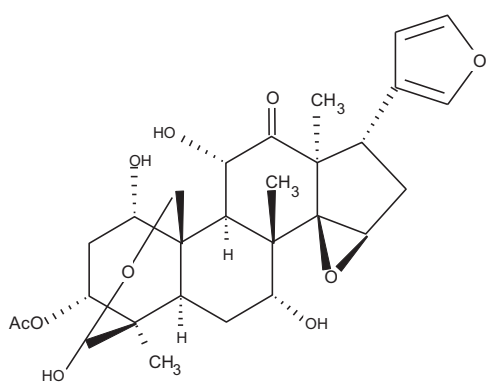

Fig. 1J. Meliartenin

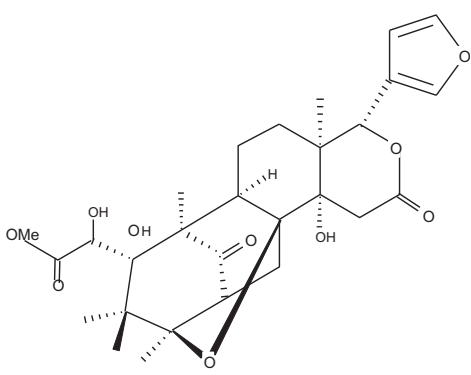

Fig. 1K. Cedrodorin

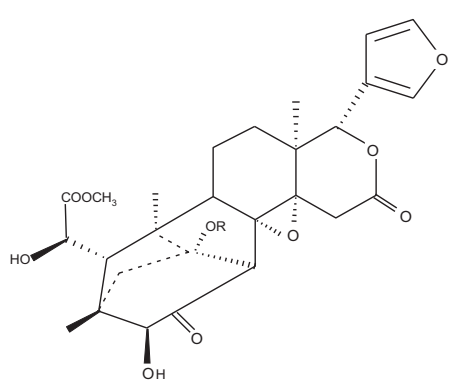

Fig. 1L. Khayanolide

FIGURE 1 | Continued 

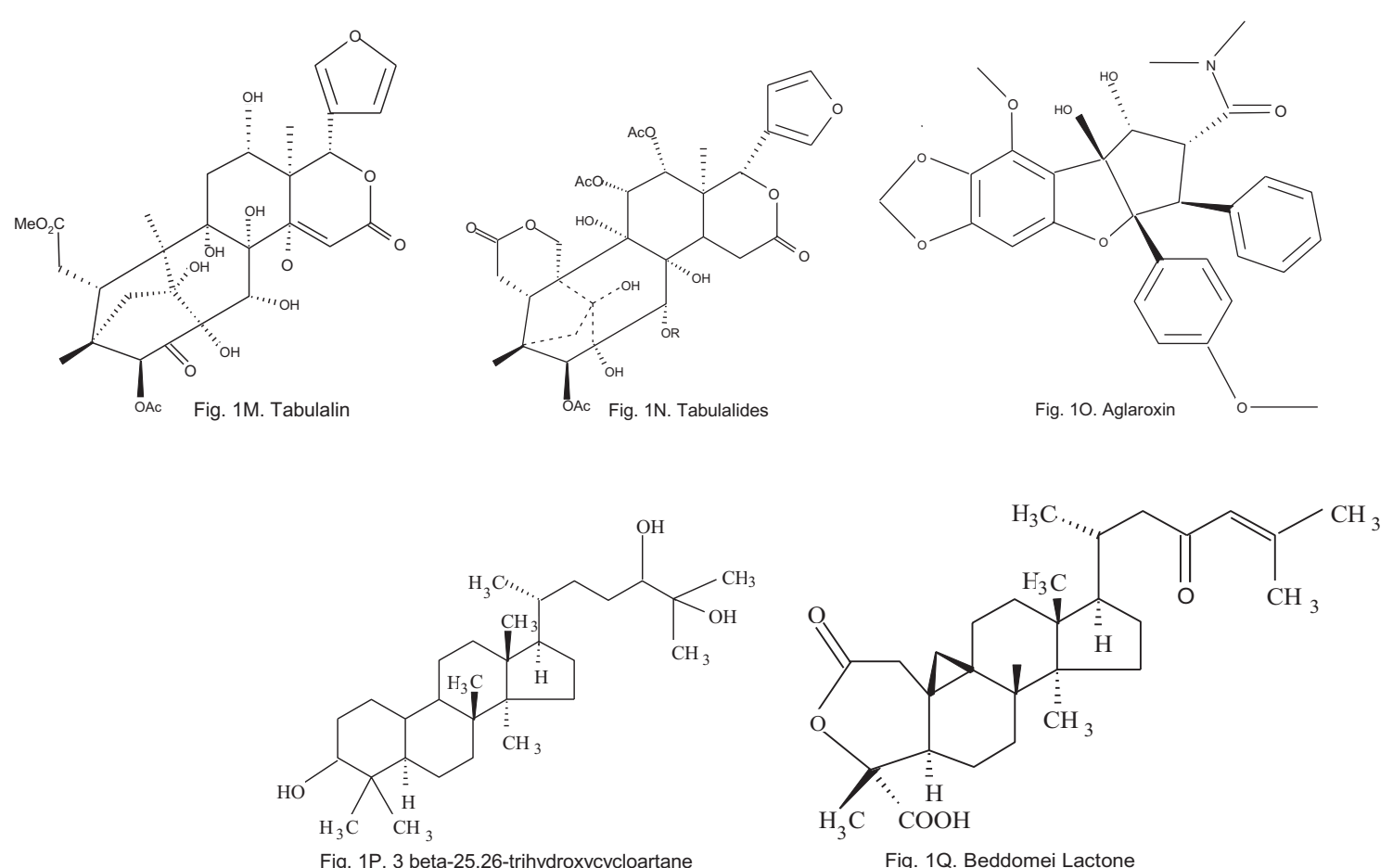

Fig. 1P. 3 beta-25,26-trihydroxycycloartane

Fig. 1Q. Beddomei Lactone

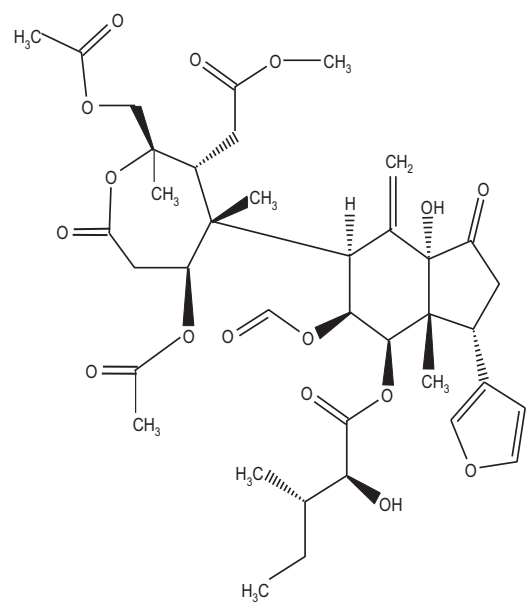

Fig. 1R. Prieurianin

FIGURE 1 | Chemical structure of secondary metabolites identified from Meliaceae plants.

growth retardation and deformities were the direct effect of azadirachtin and not due to lack of food (Kraus and Grimminger, 1981). Nutritional analyses revealed that the insect growth inhibitory and antifeedant effects were independent of each other and relative to the level of treatment with (Ruscoe, 1972; Koul and Isman, 1991). Furthermore, $48 \mathrm{~h}$ feeding of on foliage treated at 5-10 ppm appeared to be sufficient for growth disruption of $S$. litura at early instars age (Kraus and Grimminger, 1981).

The insect growth regulating activity of azadirachtin focused its effects mainly on the molt of insects (Kraus and Grimminger, 1981). Feeding on azadirachtin-sprayed creeping bentgrass caused molting disorders and death of early instar Agrotis ipsilon and slowed feeding and stunted the growth of late instars (George and Potter, 2008) caused significant reduction in feeding activity at $2.5 \mathrm{~g} / \mathrm{L}$, prolonged the period for molting to nymphal stage, and caused $60 \%$ reduction in moltability. In addition, inhibited coldinduced supernumerary molt of last-instar Galleria mellonella and induced disturbances in larval and pupal ecdysis as well as in the metamorphic process, thus resulting in the formation of various intermediates (Malczewska et al., 1988; Al-Rajhy et al., 2003).

It seemed likely that pupation in azadirachtin-treated Manduca sexta was inhibited by a disturbed ecdysteroid regulation shortly before pupal ecdysis, and was able to inhibit development even when individuals performed a complete molt 
after the treatment (Schlüter et al., 1985). In preventing normal development of final-instar larvae of Heliothis virescens, apparently reduced molting hormone titers by reducing prothoracicotropic hormone (PTTH) titers and the receptivity of prothoracic glands to produce ecdysone via stimulation by PTTH. In Mamestra brassicae $3 \mathrm{ppm}$ of azadirachtin caused degenerated spermatocysts (Shimizu, 1988). The morphological and biochemical effects induced by azadirachtin suggested a widespread blockade of factors presumably located in the central nervous system stimulated a specific deterrent neuron in the lepidopterous species tested and inhibited the firing of neurons with signal phagostimulants in another test (Rembold et al., 1984; Simmonds and Blaney, 1984).

The feeding experiments showed the ED 50 values of sendanin (Burke et al., 1977) for growth inhibition against Pectinophora gossypiella, Heliothis zea, $H$. virescens, and S. frugiperda ranged from 9 to $60 \mathrm{ppm}$, with $P$. gossypiella being the most sensitive and Heliothis complex the least (Kubo and Klocke, 1982a,b). When incorporated into artificial diets of neonates at $50 \mathrm{ppm}$, humilinolides A-D (Niven and Taylor, 1988; Anderson and Ley, 1990; Anderson et al., 1991; Zhang et al., 2008a,b) caused larval mortality, as well as growth reduction and increased the development time of survivors in a concentration-dependent manner. In addition at $5 \mathrm{ppm}$ also reduced growth and survivorship of Ostrinia nubilalis.(Jimenez et al., 1997a,b), Swietenin C (Zhang et al., 2008a,b), humilinolide E (Harrison et al., 1970), methyl-2-hydroxy- 3 $\beta$-isobutyroxy-1-oxomeliac-8(30)-enate (Qi et al., 2004), and humilin B (Nicolaou et al., 2002) reduced survivorships at various stages against Ostrinia nubilalis, while $6 \alpha$-acetoxygedunin (Akisanya et al., 1961) reduced growth at the test concentration of $50 \mathrm{ppm}$. (Jimenez et al., 1998), febrifugin A (Da Silva et al., 2008), the last showed the highest insecticidal activity at $50.0 \mathrm{mg} / \mathrm{kg}$ against $S$. frugiperda. Further 20, 21, 22, 23-tetrahydro-23-oxoazadirone (Kadota et al., 1990) showed insecticidal activity against Peridroma saucia.

The methanolic seed extract of $M$. azedarach treatment at $1 \%$ and $10 \%$ resulted in decrease in feeding was observed in a $S$. frugiperda. When increasing the concentrations of extract the larvae digested and/or metabolized the food with minimum level. The reduction in growth was not completely due to the starvation but also due to ingestion of toxic substances from $M$. azedarach (Breuer and Schmidt, 1995).

Macleod et al. (1990) found that the meliatoxins isolated from the ethanolic fruit extract from M. azedarach var. australasica was toxic on S. litura larvae. Further Meliatoxin significantly reduced the ingestion of food at $400 \mathrm{ppm}\left(480 \mathrm{mg} / \mathrm{cm}^{2}\right)$ and they pointed out that the C-15 keto group would be responsible for the growth inhibition. There are other genera in the Meliaceae that also contain limonoids that show promising pesticide activity. But much less work has been carried out on those species (De Sousa et al., 2009).

In insect alimentary canal midgut is generally considered as a tissue where the digestive enzymes secret and is a site for digestion and absorption of nutrients. Also it is an important tissue affected by many kinds of toxicants including entomopathogens (Sutherland et al., 2002a,b). Insect gut is differentiated in three regions that include foregut, midgut, and the hindgut. Further it signifies one of the most important areas in insect physiology because of interaction between the insects and the environment. Hence it has been the focus of entomologist aiming to develop effective methods of insect pest's control (Chapman, 1998; Levy et al., 2004). Among the three regions, the midgut region has particularly been the most studied, because alterations on it affect the growth and development of insects as a result of changes in the physiological events that depend on meal intake, absorption and transformation (Mordue and Blackwell, 1993; Nisbet, 2000; De Sousa et al., 2009). The epithelium of the midgut in Lepidoptera is composed of columnar cells which are responsible for absorption and enzymes secretion, goblet cells for ionic homeostasis, endocrine cells for endocrine function and the regenerative cells for epithelium renewal (Genta et al., 2006; Pinheiro et al., 2008; De Sousa et al., 2009).

The peritrophic membrane in the midgut is important cell organelle which has a fundamental role of protection of the midgut. The peritrophic membrane is located between the gut lumen and the epithelial layer. It is a protective layer, protecting this epithelium from mechanical damage and it protect against toxic materials to the insect (Terra, 2001). Lot of works has been done on the morphological and ultrastructure of insects midgut from Lepidoptera such as Diatraea saccharalis (Fabricius), Manduca sexta L., Spodoptera frugiperda, Anticarsia gemmatalis (Hübner), Alabama argillacea (Hübner) suggest that the distribution and morphology of the epithelial cells can vary along this region (Pinheiro et al., 2003, 2008; Levy et al., 2004; De Sousa et al., 2009). These differences are usually observed at the ultrastructural level (Santos et al., 1984; Billingsley and Lehane, 1996).

Insect midgut cells synthesizing and secreting digestive enzymes. These enzymes can be divided into two types. One is constitutively secreting cells and they do not accumulate secretory products. Also synthesized enzymes may release immediately after their synthesis. Regulated secretory cells collect secretory material which is quickly released in response to a suitable signal (Lehane et al., 1995). Also during the digestion process ingested macromolecules are break down into smaller parts by the insects and it will be absorbed by the epithelial cells in midgut. Further many enzymes has play vital role during this process. During the digestive cycle, there are significant changes in the levels of midgut digestive enzymes. This suggests that digestive enzyme synthesis and secretion are controlled during the digestive process (Lehane et al., 1995).

There is four categories of control mechanism of digestive enzyme levels in insects have been identified so for. That is included as-nervous, hormonal, paracrine and prandial. Direct nervous control of digestive enzyme synthesis has been largely discounted on the grounds that innervation appears limited to motor innervation of the midgut musculature (Day and Powning, 1949; Garcia and Garcia, 1977; Žitòan et al., 1993; Lehane et al., 1995). The $\mathrm{pH}$ of gut contents is one of the most important factors that affect digestive enzymes. Many determinations have been reported so for about the luminal $\mathrm{pH}$ values in many insects with $\mathrm{pH}$ optima of their digestive enzymes. These studies headed to the claim that there is a correlation between enzyme $\mathrm{pH}$ optima and luminal $\mathrm{pH}$ in insect guts (Applebaum, 1985; Terra and Ferreira, 
1994). First, most of the $\mathrm{pH}$ data's were obtained by measuring contents of entire midguts, thus mixing contents of different midgut regions including foregut, midgut and hindgut which are now known to have contrasting $\mathrm{pH}$ values in several insects (Terra and Ferreira, 1994). Lepidopteran insects may display varying $\mathrm{pH}$ alkaline contents, particularly in the middle ventriculus, as they are herbivorous (eat leaves), wax (Galleria mellonella) or keratin (Tineola bisselliella). This high $\mathrm{pH}$ may be an adaptation of leafeating Lepidopteran families for extracting hemicelluloses from plant cell walls (Ferreira et al., 1988; Terra and Ferreira, 1994). The $\mathrm{pH}$ of the midgut is usually in the range 6-7.5. The higher alkalinity of the midgut contents ( $\mathrm{pH} 9-12)$ was already described in Lepidopteran (Houseman and Downe, 1980; Terra, 1990).

Digestive enzymes are hydrolases. Enzymes liable for the hydrolysis of proteins down to amino acids are the proteases. Proteases (peptide hydrolases, EC 3.4) are enzymes acting on peptide bonds and include the proteinases (endopeptidases, EC 3.4.21-24) and the exopeptidases (EC 3.2.4.11-19). Proteinases are divided into sub-classes on the origin of catalytic mechanism (Terra and Ferreira, 1994; Lehane et al., 1995; Terra et al., 1996; Shekari et al., 2008). Trypsins (EC 3.4.21.4) are serine proteinases that will cleave protein chains on the carboxyl side of basic Lamino acids. The enzyme is exactly inhibited by $\mathrm{N}$ - $\alpha$-tosyl-Llysine chloromethyl keton which acts on histidine (Shaw et al., 1965; Terra and Ferreira, 1994). Apart from this Chymotrypsins (EC 3.4.21.1), cathepsin B (EC 3.4.22.1.), pepsin (EC 3.4.23.1), Aminopeptidases (EC 3.4.11.), Carboxypeptidases (EC 3.4.1618) and Dipeptidases (EC 3.4.13.) are major proteases digestive enzymes.

Carbohydrase is responsible for catalyzes the breakdown of carbohydrates into simple sugars. It includes $\alpha$-Amylase (EC 3.2.1.1), $\beta$-amylase (EC 3.2.1.2), glucoamylase (EC 3.2.1.3), exo- $\beta$-1,4-glucanases (EC 3.2.1.91), endo- $\beta$-1,4-glucanases (EC 3.2.1.4), $\beta$-1,4-glucosidases (EC 3.2.1.21), chitinase (EC 3.2.1.14), $\beta$-Nacetyl-D-glucosaminidase (EC 3.2.1.52), Lysozyme (EC 3.2.1.17), Lysozyme (EC 3.2.1.17), $\alpha$-Glucosidases (EC 3.2.1.20), and Trehalase (EC 3.2.1.28) (Wyatt, 1967; Huber and Mathison, 1976; Applebaum, 1985; Dunn, 1986; Kramer and Koga, 1986; Martin et al., 1991). Further Christeller et al. (1992) identified midgut protease activities in midgut was higher in Lepidopteran insects from the families, Tortricidae, Noctuidae, Gelechiidae, Hepialidae and Pyralidae. Further treatment with chemical insecticides has directly affected the digestive enzyme including amylase, invertase, lipase, and protease (Deshmukh et al., 2009).

Alkaline phosphatase (ALP, E.C.3.1.3.1) and acid phosphatase (ACP, E.C.3.1.3.2) are hydrolytic enzymes, which hydrolyse phosphomonoesters under acid or alkaline conditions, respectively. ALP is mainly found in the intestinal epithelium of animals and its primary function is to provide phosphate ions from mononucleotide and ribonucleo-proteins for a variety of metabolic processes. ALP is involved in the transphosphorylation reaction (Sakharov et al., 1989). Adenosine triphosphatases (ATPases) are essential for the transport of glucose, amino acids, and other organic molecules. Any impairment in their activity will affect the physiology of the insect gut. These enzymes are located in the midgut, malpighian tubules, muscles, and nerve fibers of the Lepidopertan insects (Horie, 1958). Midgut has the highest
ALP and ACP activity as compared to other tissues. The ALP and ACP activities are low during the larval moulting stage and increased gradually after moulting (Miao, 2002). The highest activity appeared before the full appetite gluttonous stage fifth instar and the lowest activity was found in the mature larval stage (Miao, 2002; Senthil-Nathan et al., 2005a,b,c,d).

Lactate dehydrogenase (LDH) (EC 1.1.1.28) is an important glycolytic enzyme present in virtually all animal tissues (Kaplan and Pesce, 1996). It is also involved in carbohydrate metabolism and has been used to indicate exposure to chemical stress ( $\mathrm{Wu}$ and Lam, 1997; Diamantino et al., 2001). LDH is a parameter widely used in toxicology and in clinical chemistry to diagnose cell, tissue and organ damage. However, the potential of this enzyme as an indicative criterion in invertebrate toxicity tests has been scarcely explored (Ribeiro et al., 1999).

\section{EFFECT OF MELIACEAE SECONDARY METABOLITES ON NUTRITIONAL INDICES}

Nutritional/food utilization efficiencies of insects characteristically calculated and expressed as percentages of approximate digestibility $(\mathrm{AD})$ or assimilation efficiency (AE- absorption or digestive efficiency) estimates the percentage of ingested food that is digested and assimilated. Efficiency of conversion of digested food (ECD) or net growth efficiency (NGE; sometimes metabolic efficiency) estimates the percentage of assimilated food that is converted to biomass; and efficiency of conversion (to biomass) of ingested food (ECI) or gross growth efficiency (GGE- growth efficiency) estimates the percentage of ingested food that is converted to biomass (Waldbauer, 1968; Slansky, 1985; Slansky and Scriber, 1985).

Incorporation of azadirachtin, salannin, and nimbinene limonoids from neem into the artificial diet of fourth instar larvae significantly reduced the consumption and relative growth of S. litura larvae compared to controls at 4,8 , and $1.2 \mathrm{ppm}$ concentrations tested. But Efficiency of conversion of ingested and digested food (ECI and ECD) into biomass of S. litura larvae was not reduced. Approximate digestibility (AD) was continued to be same in all treatments. Interestingly, both ECI and ECD were reduced at all doses after topical application 0.1, 0.5, and $1 \mu \mathrm{g} /$ Ins of azadirachtin to fourth instar larvae with a considerable decrease in relative growth rate. The reduction in the food utilization experiment was regardless of any significant change in relative consumption rate (Koul et al., 1996).

Treatment with aglaroxin A (Figure 10) (1, 3, and 5ppm) from Aglaia elaeagnoidea caused reduced RGR and RCR with a significant change in the ECI values on both $H$. armigera and $S$. litura. Reduction in growth was not only correlated with dietary concentrations. When the compounds were applied topically to the 3rd instar larvae, significantly affect the larval growth and ECI parameters but the consumption was not reduced significantly (Koul et al., 2005). Further Koul et al. (2005) confirmed physiological toxicity of aglaroxin A by comparing of RGR and RCR values. They proved the reduced growth of these larvae under the effect of aglaroxin A was not completely due to starvation; some of the growth reduction was due to the toxic effect of aglaroxin A.

Further Wheeler and Isman (2001) described 25, 50, 75, 100, and $250 \mathrm{ppm}$ of dietary concentration and 2.5, 5.0, and 10 topical 
applied doses $\left(\mu \mathrm{g} \mathrm{insect}^{-1}\right)$. Nutritional analyses revealed that the extract also acts as a chronic toxin when ingested by larvae. The crude extract, when incorporated into artificial diet reduced RGR, RCR, ECI, and ECD in a dose dependent manner.

Plotting relative growth rates against consumption rates was used to estimate the differentiation between the treatment doses and control in toxicological assay. Two lines were generated for each: one calibration curve, where a range of RCRs were generated and correlated to the RGRs, and one test line, where the larvae were fed diets containing different treatment doses of compound concentrations. The RGR and RCR for each set of larvae were subjected to a linear regression analysis (Figures 2, 3). The slope (regression coefficient) of the regression line

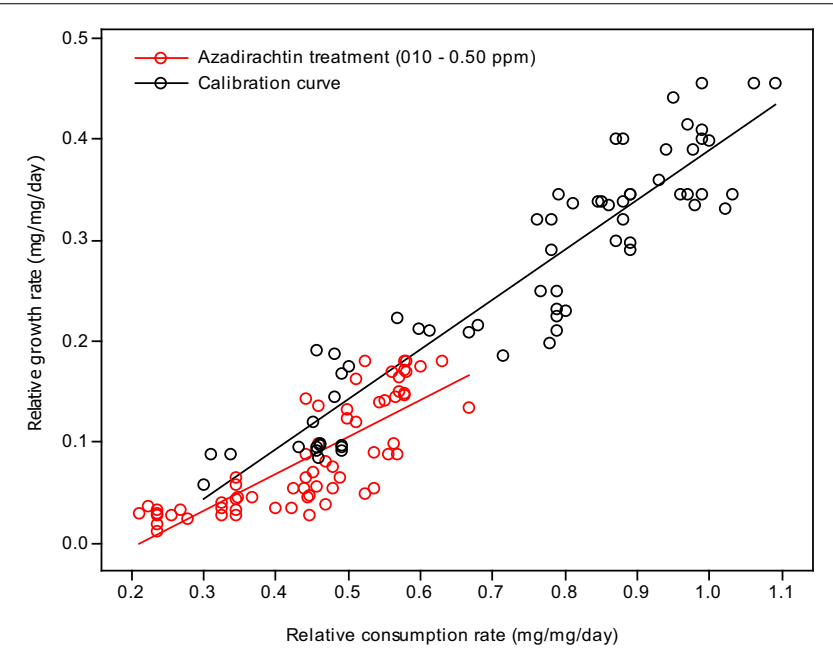

FIGURE 2 | Correlation between the relative consumption rates and relative growth rates of $\boldsymbol{C}$. medinalis fed on different quantities of control diet (calibration curve) and larvae fed on diet containing different concentrations of azadirachtin.

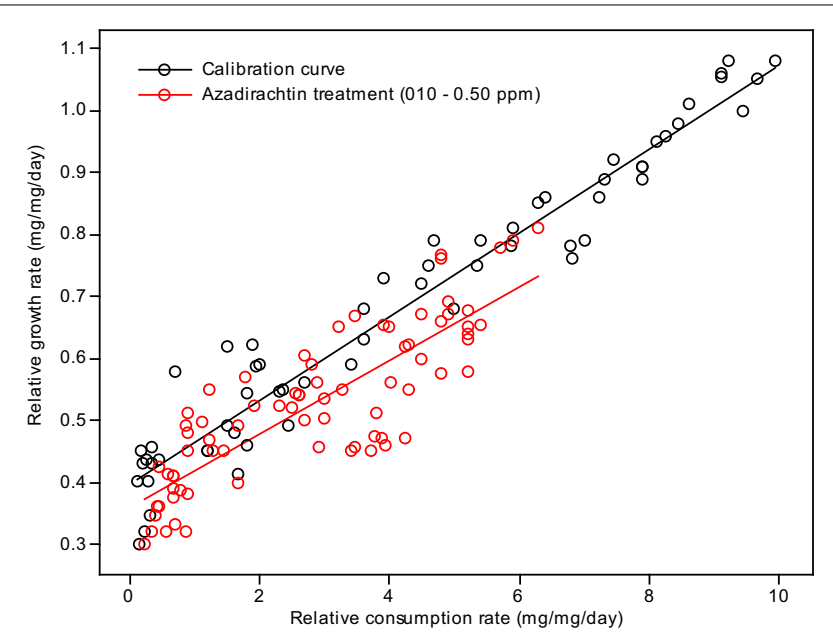

FIGURE 3 | Correlation between the relative consumption rates and relative growth rates of $\boldsymbol{S}$. litura fed on different quantities of control diet (calibration curve) and larvae fed on diet containing different concentrations of azadirachtin. represents the growth efficiency of the larvae. The two regression coefficients were compared by calculating the variance of the difference between the two estimates of the regression coefficients (Anderson et al., 1977; Searle, 1977; Wheeler and Isman, 2001; Koul et al., 2005; Senthil-Nathan et al., 2009; Chandrasekaran et al., 2012). This test showed that the growth efficiency of Cnaphalocrocis medinalis Guenée and S. litura fed on a treated diet was significantly less than that of the control larvae with the insects fed in three different concentrations growing differently for a given RCR. This again indicates that the reduced growth of these larvae under the influence of azadirachtin is not entirely due to starvation; some of the growth reduction is due to toxic effect of the pure limonoids azadirachtin.

Barnby and Klocke (1987) have reported neem feeding inhibition to a direct action of azadirachtin on the "centers that control feeding and metabolism." Although azadirachtin treatment decreased food intake by $S$. littoralis larvae, this reduction alone would not explain the pronounced inability of the larvae to gain weight in the instars immediately after treatment. Reductions in weight gain were also observed in the sixth instar, but accompanied by no reduction in food intake in S. litura and (Ayyangar and Rao, 1989; Ramachandran et al., 1989) and S. exempta (Tanzubil and McCaffery, 1990).

Wheeler and Slansky (1991) and Slansky (1993) described that digestibility may not be closely connected with retention time of food in the gut. Adverse effects of azadirachtin on midgut epithelial cells, which might disrupt enzyme secretion and nutrient absorption, have been reported (Nasiruddin and Mordue Luntz, 1993).

Timmins and Reynolds (1992) pointed out a reduction in the efficiency of food utilization following $M$. sexta treatment with azadirachtin to increased energetic costs arising from a reduced ability to utilize dietary nitrogen, which would not necessarily interfere with absorption from the gut (digestibility). They further pointed out that, in the absence of an essential supply of minerals, amino acids and other nutrients then in excess for growth might be diverted into other metabolic pathways. Many of researchers have further proposed that such other pathways might include those involved in detoxification of allelochemicals like limonoids (Arnason et al., 1985; Barnby and Klocke, 1987; Tanzubil and McCaffery, 1990; Martinez and Van Emden, 1999; Senthil-Nathan et al., 2005d, 2007; Senthil-Nathan, 2006).

Experiments with azadirachtin on C. medinalis and S. litura were carried out to investigate whether the efficacy was purely a feeding deterrence or toxicity mediated physiological inhibition (Senthil-Nathan, unpublished data). Using food utilization measurement, it was established that there was a reduction in growth rate associate with the decrease in consumption, which accounted partially for the decrease in growth rate as there was a reduction in ECI values. ECI is a complete measure of an insect's capacity to utilize the food that it ingests for growth. Therefore, a change in ECI values indicates that ingested secondary metabolites exhibit toxicity, and is not just an antifeedent affect (Koul et al., 2005).

Reduced RGR and RCR was also observed after treatment with M. azedarach on S. frugiperda (Breuer and Schmidt, 1996) and C. medinalis (Senthil-Nathan, 2006a,b,c). 


\section{EFFECT OF MELIACEAE SECONDARY METABOLITES ON DIGESTIVE ENZYMATIC PROFILES OF LEPIDOPTERA}

The effects of neem derivatives azadirachtin on the fourth instar larvae of Plodia interpunctella Guenée, resulted in severe reduction in protein, glycogen and lipid contents 7 days after treatment. Further the $\alpha$-amylase activity on polyacrylamide gel showed a weak enzymatic activity in larvae fed azadirachtin indicating a severe reduction in a-amylase activity (Rharrabe et al., 2008). Further treatment with azadirachtin directly/indirectly inhibits the production of trypsin by the enzyme-secreting cells of the midgut wall of M. sexta (Timmins and Reynolds, 1992). Also Timmins and Reynolds (1992) suggest that inhibition of either synthesis or release of trypsin due to azadirachtin might be a direct action on the enzyme-secreting cells of the midgut wall. Azadirachtin may act indirectly, by disturbing some mechanism that might control trypsin secretion. Most of the Lepidopteran insect, possess endocrine cells associated with the midgut wall (Endo and Nishiitsutsuji-Uwo, 1980). The endocrine cells may responsible for local control of enzyme secretion into the gut lumen. Further circulating hormones from the classical neuroendocrine system might act to control enzyme levels. These are all preliminary finding but it is well-known that known that azadirachtin may affect the secretory function of neuroendocrine cells in insects (Barnby and Klocke, 1990; Garcia et al., 1990). Rharrabe et al. (2008) observed that exposure to azadirachtin, a significant decrease in protein, glycogen and lipid contents was observed in P. interpunctella Hübner. The reduction of such biochemical contents can be due to major mobilization of these substances in reaction to the absence of nutrients caused by the toxic effect of azadirachtin on the midgut and a decrease of their synthesis. The walls and epithelial cell of the digestive tract in insects have a high content of detoxification enzymes, as a barrier to plant secondary metabolites hat they may consume with the diet (Ortego et al., 1999).

Hasheminia et al. (2011) has clearly pointed out that treatment with plant extract to Lepidopteran insect hinder the link between the carbohydrates and protein metabolism and are altered during various physiological processes aminotransferases. Further they stated that plant extracts exhibited an endocrine disruption by way of progressive or retrogressive larval duration, this explanation could be pointed out for reduced alanine aminotrasferase (ALT) and aspartate aminotransferase (AST). Smirle et al. (1996) stated that changes in metabolism and decreases in the protein content of neem-treated individuals may be expected to affect enzyme titers of Choristoneura rosaceana L. especially glutathione S-transferases.

Senthil-Nathan et al. (2004) observed that changes in acid phosphatases (ACP), alkaline phosphatases (ALP) and adenosine triphosphatases (ATPase) activities after treatment with neem extracts in C. medinalis. They concluded that changing the physiological balance of the midgut might affect the enzyme activity. ALP is involved in the transphosphorylation reaction. In their study, the decrease in the activity of these enzymes after treatment with neem extract suggests that these materials affect gut physiological events (i.e., ion transport) that might influence these enzymes (Phillips et al., 1988). Decreased level of $\mathrm{ACP}$ at higher concentration of neem extract suggests reduced phosphorus liberation for energy metabolism, decreased rate of metabolism, as well as decreased rate of transport of metabolites, and may be due to the direct effect of neem seed extract on $C$. medinalis (Senthil-Nathan et al., 2004, 2006d,e).

ATPases are essential for transport of glucose, amino acids, etc. Any impairment in their activity will affect the physiology of the gut. The role of membrane lipids and their micro-environmental changes at the physical and chemical levels may be responsible for the differential response observed at the level of ATPase activity after treatment with neem extract against the $C$. medinalis. Membrane ATPase, especially in the intestinal epithelium, assists transport and reabsorption of metabolites and nutrients and also secondary transport of ions and non-electrolytes (Lechleitner and Phillips, 1988; Fogg et al., 1991). Babu et al. (1996) showed that the ATPase activity in the gut of $H$. armigera was significantly decreased, due to toxic effects of azadirachtin. ATPase inhibition may affect active ion transport, leading to alteration in electrolyte regulation. After neem extract treatment a decrease in enzymatic activity denotes reduced metabolism in the insect and may be due to the toxic effects neem compounds on membrane permeability, especially on the gut epithelium (Figure 4) (Senthil-Nathan et al., 2005a,b, 2007).

Meliaceous plant compounds indicate that there may be effects on enzyme titers and activities (Klocke, 1989; Feng et al., 1995). Feeding is necessary for the stimulation of digestive enzyme activities (Smirle et al., 1996; Shekari et al., 2008) and may have interfered with the enzyme-substrate complex thus affecting the peristaltic movement of the gut (Broadway and Duffey, 1988; Duffey and Stout, 1996) a phenomenon that was very clear observed by the decrease of fecal pellet production in the $M$. azedarach treatment (Senthil-Nathan, 2006).

Lactate dehydrogenase (LDH) (EC 1.1.1.27) is involved in the production of energy, being particularly important when a considerable amount of additional energy is required immediately. A negative correlation between LDH activity and ambient oxygen levels for some aquatic organisms were suggesting a possible biochemical adjustment in response to the lowered oxygen

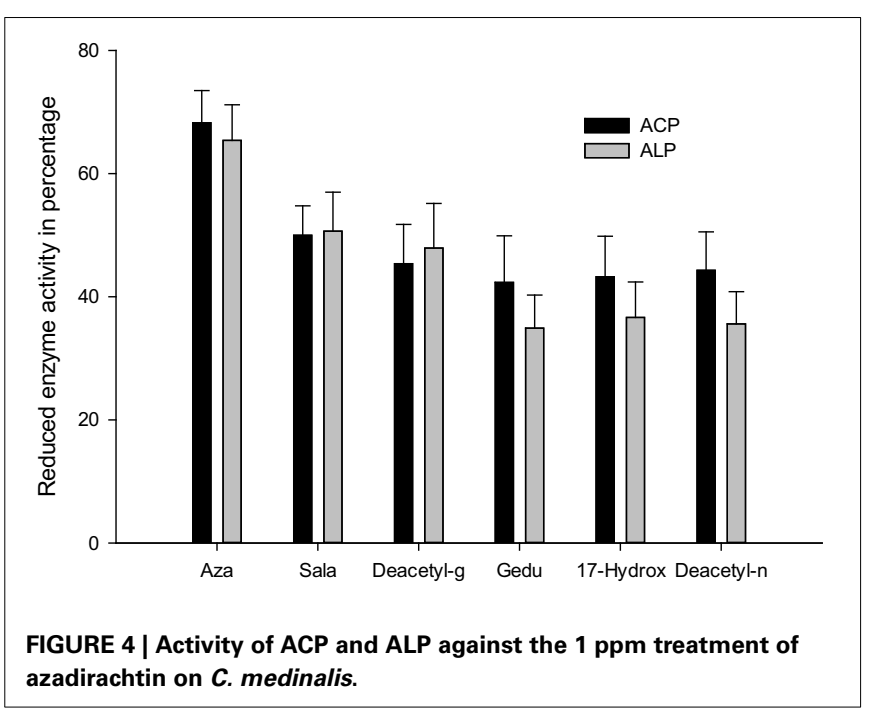


levels. This probably occurs also in situations of chemical stress. Therefore, this enzyme may be a sensitive criterion in laboratory (Zebe and McShan, 1957). After treatment with neem limonoids a decrease in LDH activity denotes reduced metabolism in the insect and may be due to the toxic effects of neem derivatives on membrane permeability, especially of the gut epithelium (Figures 5-7) (Senthil-Nathan et al., 2005b, 2006a,b,c,d,e; Zibaee et al., 2008). Further Mitchell et al. (1997) identified neem compounds inhibit ecdysone 20-monooxygenase activity associated with fat body and midgut of fifth instar larvae of $M$. sexta.

\section{EFFECT OF MELIACEAE SECONDARY METABOLITES ON NADPH CYTOCHROMEC REDUCTASE AND CHOLINESTERASE}

Artificial diet containing $0.01 \%$ of an ethyl acetate fraction of M. azedarach fruit extract inhibited the cholinesterase activity of the larvae of S. frugiperda (Breuer et al., 2003). It is known that

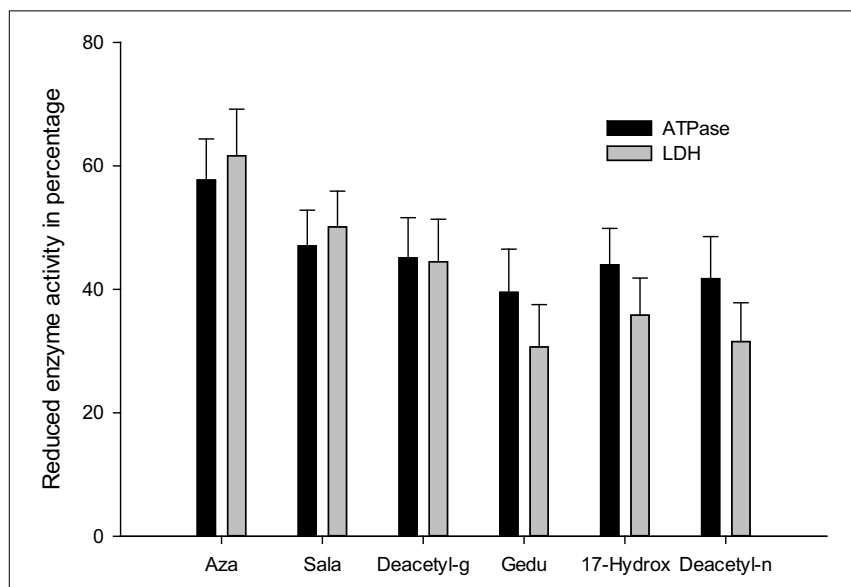

FIGURE 5 | Activity of ATPase and LDH against the $1 \mathrm{ppm}$ treatment of azadirachtin on $C$. medinalis.

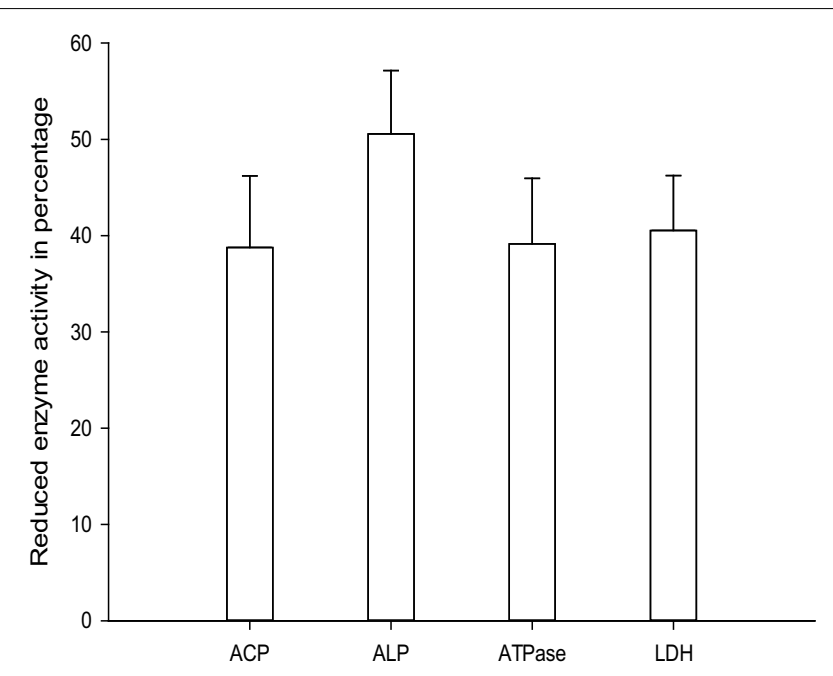

FIGURE 6 | Midgut enzyme activity of $S$. litura after treatment with 1 ppm azadirachtin. this detoxification system becomes more Role of $M$. azedarach L. (Meliaceae) for the control of insects activated as larvae develop (Breuer et al., 2003), which would explain the lower sensitivity to treatments of the bigger larvae (Breuer and Schmidt, 1996; Yasmin et al., 2010).

This increase suggests that the cytochrome-P-450-system might be involved in the detoxification mechanism, because this enzyme is the most important flavoprotein component within the microsomal electron transfer chain. Cytochrome-P-450 enzymes are known to degrade various substrates, especially lipophilic ones (toxicants) and are involved in the elimination of insecticides. The capacity to inactivate natural compounds, such as flavenoids and terpenoids, has also been demonstrated before (Brattsten et al., 1977; Dowd et al., 1983; Yu, 1983). Similar components are present in M. azedarach (Kraus, 1986; Breuer et al., 2003). Bullangpoti et al. (2012) proved that in vitro experiments with $M$. azedarach senescent leaf extracts inhibit esterases and P450 enzymes. Also Feng et al. (1995) clearly pointed out the extract of M. toosendan inhibit midgut esterases of S. litura

This review indicates that there is a possible interaction between Meliaceae secondary metabolites and gut enzymes. Meliaceae limonoids like azadirachtin may directly influence

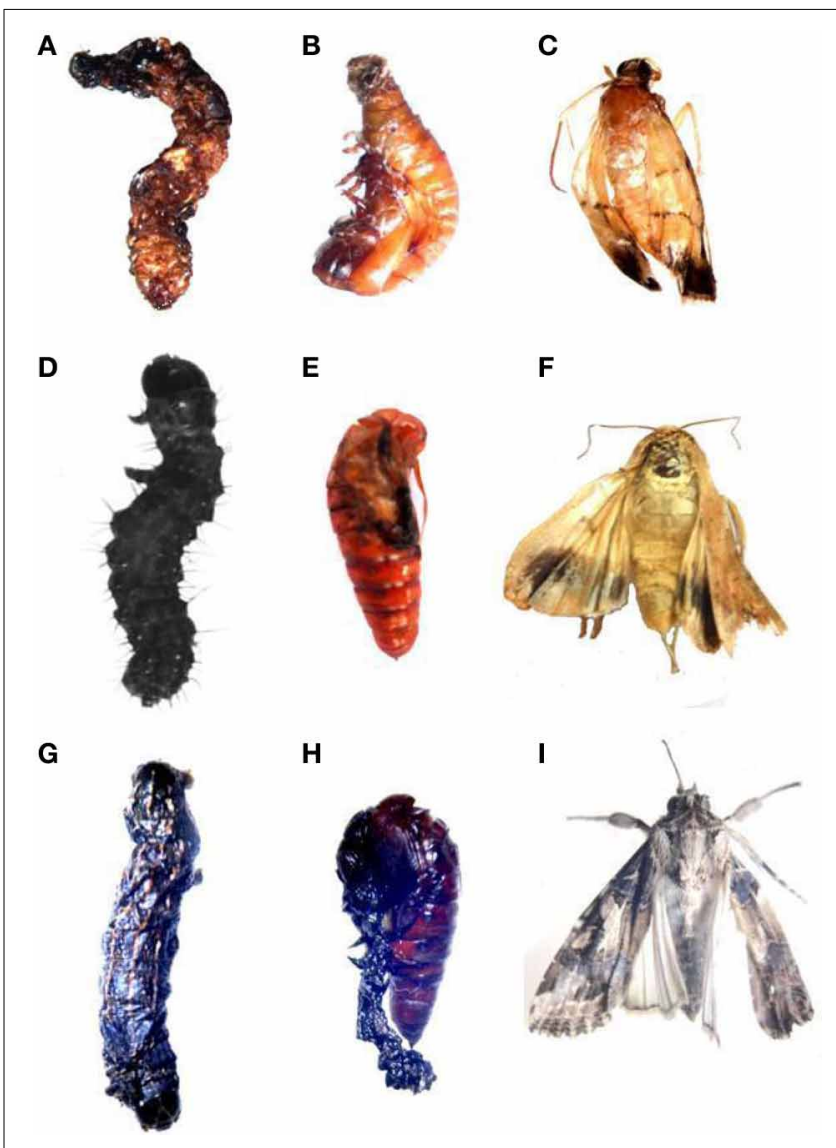

FIGURE 7 | Larval deformities of Lepidopteran insects after treatment with 0.5 ppm of Azadirachtin. (A-C) C. medinalis larval, pupal and adult deformities. (D-F) H. armigera larval, pupal and adult deformities. (G-I) $S$. litura larval, pupal and adult deformities. 
the expression of this receptor (Huang et al., 2004) it could cause a major disruption to the growth, and development of an insect. Further it could make Meliaceae secondary metabolites an important tool in the management of resistant populations of Lepidopteran where enzyme based metabolism is involved.

\section{REFERENCES}

Abdelgaleil, S. A., Okamura, H., Iwagawa, T., Sato, A., Miyahara, I., Doe, M., et al. (2001). Khayanolides, rearranged phragmalin limonoid antifeedants from Khaya senegalensis. Tetrahedron 57, 119-126. doi: 10.1016/S0040-4020(00) 00994-7

Akisanya, A., Bevan, C., Halsall, T., Powell, J., and Taylor, D. (1961). West African timbers. Part IV. Some reactions of gedunin. J. Chem. Soc. 720, 3705-3708. doi: 10.1039/jr9610003705

Al-Rajhy, D. H., Alahmed, A. M., Hussein, H. I., and Kheir, S. M. (2003). Acaricidal effects of cardiac glycosides, azadirachtin and neem oil against the camel tick, Hyalomma dromedarii (Acari: Ixodidae). Pest Manag. Sci. 59, 1250-1254. doi: $10.1002 /$ ps.748

Anderson, J. C., and Ley, S. V. (1990). Chemistry of insect antifeedants from Azadirachta indica (part 7): preparation of an optically pure hydroxyacetal epoxide related to azadirachtin. Tetrahedron Lett. 31, 3437-3440. doi: 10.1016/S00404039(00)97416-1

Anderson, J. C., Ley, S. V., Santafianos, D., and Sheppard, R. N. (1991). Chemistry of insect antifeedants from Azadirachta indica (part 8): synthesis of hydroxyl dihydrofuran acetal fragments for biological evaluation and azadirachtin total synthesis studies. Tetrahedron 47, 6813-6850. doi: 10.1016/S0040-4020(01) 82332-2

Anderson, R., Quaas, R., and Searle, S. (1977). Fourth Moments in the General Linear Model; and the Variance of Translation Invariant Quadratic Forms. Paper No. BU-630-M in the Biometrics Unit Mimeo Series (Ithaca, NY: Cornell University).

Applebaum, S. (1985). Biochemistry of digestion. Comp. Insect Physiol. Biochem. Pharmcol. 4, 279-311.

Arnason, J., Philogene, B., Donskov, N., Hudon, M., McDougall, C., Fortier, G., et al. (1985). Antifeedant and insecticidal properties of azadirachtin to the European corn borer, Ostrinia nubilalis. Entomol. Exp. Appl. 38, 29-34. doi: 10.1111/j.1570-7458.1985.tb03494.x

Arnason, J., Philogene, B., Donskov, N., and Kubo, I. (1987). Limonoids from the Meliaceae and Rutaceae reduce feeding, growth and development of Ostrinia nubilalis. Entomol. Exp. Appl. 43, 221-226. doi: 10.1111/j.15707458.1987.tb02213.x

Arpaia, S., and Loon, J. V. (1993). Effects of azadirachtin after systemic uptake into Brassica oleracea on larvae of Pieris brassicae. Entomol. Exp. Appl. 66, 39-45. doi: 10.1111/j.1570-7458.1993.tb00690.x

Ascher, K. (1993). Nonconventional insecticidal effects of pesticides available from the neem tree, Azadirachta indica. Arch. Insect Biochem. Physiol. 22, 433-449. doi: 10.1002/arch.940220311

Atwal, A. S., and Pajni, H. R. (1964). Preliminary studies on the insecticidal properties of drupes of Melia azedarach against caterpillar of Pieris brassicae L. (Lepidoptera: Pieridae). Indian J. Entomol. 26, 221-227.

Ayyangar, G., and Rao, P. (1989). Neem (Azadirachta indica A. Juss) extracts as larval repellents and ovipositional deterrents to Spodoptera litura (Fabr.). Indian J. Entomol. 51, 121-124.

Babu, R., Murugan, K., and Vanithakumari, G. (1996). Interference of Azadirachtin on the food utilization efficiency and midgut enzymatic profiles of Helicoverpa armigera. Indian J. Environ. Toxicol. 6, 81-84.

Barnby, M. A., and Klocke, J. A. (1987). Effects of azadirachtin on the nutrition and development of the tobacco budworm, Heliothis virescens (Fabr.) (Noctuidae). J. Insect Physiol. 33, 69-75. doi: 10.1016/0022-1910(87)90076-X

Barnby, M. A., and Klocke, J. A. (1990). Effects of azadirachtin on levels of ecdysteroids and prothoracicotropic hormone-like activity in Heliothis virescens (Fabr.) larvae. J. Insect Physiol. 36, 125-131. doi: 10.1016/00221910(90)90183-G

Billingsley, P., and Lehane, M. (1996). "Structure and ultrastructure of the insect midgut," in Biology of the Insect Midgut, eds M. J. Lehane and P. F. Billingsley (London: Springer), 3-30.

Bogorni, P. C., and Vendramim, J. D. (2005). Sublethal effect of aqueous extracts of Trichilia spp. on Spodoptera frugiperda (JE Smith) (Lepidoptera: Noctuidae) development on maize. Neotrop. Entomol. 34, 311-317. doi: 10.1590/S1519566X2005000200020

Brattsten, L., Wilkinson, C., and Eisner, T. (1977). Herbivore-plant interactions: mixed-function oxidases and secondary plant substances. Science 196, 1349-1352. doi: 10.1126/science.196.4296.1349

Breuer, M., and Devkota, B. (1990). Control of Thaumetopoea pityocampa (Den. \& Schiff.) by extracts of Melia azedarach L. (Meliaceae). J. Appl. Entomol. 110, 128-135. doi: 10.1111/j.1439-0418.1990.tb00106.x

Breuer, M., and Schmidt, G. (1996). Effect of Melia azedarach extract incorporated into an artificial diet on growth, development and fecundity of Spodoptera frugiperda (JE Smith) (Lep., Noctuidae). Z. Pflanzenkr. Pflanzenschutz 103, 171-194.

Breuer, M., and Loof, A. D. (1998). Meliaceous plant preparations as potential insecticides for control of the oak processionary, Thaumetopoea processionea (L.) (Lepidoptera: Thaumetopoeidae). Mededelingen-Faculteit Landbouwkundige en Toegepaste Biologische Wetenschappen Universiteit Gent 63, 529-536.

Breuer, M., and Schmidt, G. (1995). Influence of a short period treatment with Melia azedarach extract on food intake and growth of the larvae of Spodoptera frugiperda (JE Smith) (Lep., Noctuidae). Z. Pflanzenkr. Pflanzenschutz 102, 633-654.

Breuer, M., Hoste, B., De Loof, A., and Naqvi, S. (2003). Effect of Melia azedarach extract on the activity of NADPH-cytochrome $c$ reductase and cholinesterase in insects. Pestic. Biochem. Physiol. 76, 99-103. doi: 10.1016/S0048-3575(03) 00067-1

Broadway, R. M., and Duffey, S. S. (1988). The effect of plant protein quality on insect digestive physiology and the toxicity of plant proteinase inhibitors. J. Insect Physiol. 34, 1111-1117. doi: 10.1016/0022-1910(88)90213-2

Bruce, Y. A., Gounou, S., Chabi-Olaye, A., Smith, H., and Schulthess, F. (2004). The effect of neem (Azadirachta indica A. Juss) oil on oviposition, development and reproductive potentials of Sesamia calamistis Hampson (Lepidoptera: Noctuidae) and Eldana saccharina Walker (Lepidoptera: Pyralidae). Agric. Forest Entomol. 6, 223-232. doi: 10.1111/j.1461-9555. 2004.00218.x

Brunherotto, R., and Vendramim, J. D. (2001). Bioatividade de extratos aquosos de Melia azedarach L. sobre o desenvolvimento de Tuta absoluta (Meyrick) (Lepidoptera: Gelechiidae) em tomateiro. Neotrop. Entomol. 30, 455-459. doi: 10.1590/S1519-566X2001000300019

Bullangpoti, V., Wajnberg, E., Audant, P., and Feyereisen, R. (2012). Antifeedant activity of Jatropha ossypifolia and Melia azedarach senescent leaf extracts on Spodoptera frugiperda (Lepidoptera:Noctuidae) and their potential use as synergists. Pest Manag. Sci. 268, 1255-1264. doi: 10.1002/ps.3291

Burke, B., Chan, W., Rawle, J., and Taylor, D. (1977). Correlation of anthothecol and hirtin. Cell. Mol. Life Sci. 33, 578-579. doi: 10.1007/BF01946506

Butterworth, J. H., and Morgan, E. (1968). Isolation of a substance that suppresses feeding in locusts. Chem. Commun. 4, 23-24. doi: 10.1039/c19680000023

Caballero, C., López-Olguín, J., Ruiz, M., Ortego, F., and Castañera, P. (2008). Antifeedant activity and effects of terpenoids on detoxication enzymes of the beet armyworm, Spodoptera exigua (Hübner). Spanish J. Agric. Res. 6, 177-184. doi: 10.5424/sjar/200806s1-386

Carson, R. (1951). The Sea Around Us. New York, NY: Oxford University Press.

Céspedes, C. L., Calderón, J. S., Lina, L., and Aranda, E. (2000). Growth inhibitory effects on fall armyworm Spodoptera frugiperda of some limonoids isolated from Cedrela spp. (Meliaceae). J. Agric. Food Chem. 48, 1903-1908. doi: 10.1021/jf990443q

Champagne, D. E., Isman, M. B., and Towers, G. N. (1989). Insecticidal activity of phytochemicals and extracts of the Meliaceae. Insecticides Plant Orig. 387, 95-109. doi: 10.1021/bk-1989-0387.ch008

Chandrasekaran, U., Xiaojuan, W., and Aizhong, L. (2013). Characterization, expression profiling and heterologous function analysis of two oleosin genes PvOle1 and PvOle2 from Sacha Inchi (Plukenetia volubilis). Int. J. Agr. Biol. 15, 435-442.

Chandrasekaran, R., Revathi, K., Nisha, S., Kirubakaran, S.A., Sathish-Narayanan, S., and Senthil-Nathan, S. (2012). Physiological effect of chitinase purified from Bacillus subtilis against the tobacco cutworm Spodoptera litura Fab,). Pestic. Biochem. Physiol. 104, 5-71. doi: 10.1016/j.pestbp. 2012.07.002

Chapman, R. F. (1998). The Insects: Structure and Function. New York, NY: Cambridge university press. doi: $10.1017 /$ CBO9780511818202 
Chari, M., and Muralidharan, C. (1985). Neem (Azadirachta indica Linn.) as feeding deterrent of castor semilooper (Achaea janata Linn.). J. Entomol. Res. 9, 243-245.

Charleston, D., Kfir, R., Vet, L., and Dicke, M. (2005). Behavioural responses of diamondback moth Plutella xylostella (Lepidoptera: Plutellidae) to extracts derived from Melia azedarach and Azadirachta indica. Bull. Entomol. Res. 95, 457-465. doi: 10.1079/BER2005377

Chen, W., Isman, M., and Chiu, S. F. (1995). Antifeedant and growth inhibitory effects of the limonoid toosendanin and Melia toosendan extracts on the variegated cutworm, Peridromasaucia (Lep., Noctuidae). J. Appl. Entomol. 119, 367-370. doi: 10.1111/j.1439-0418.1995.tb01302.x

Chiu, S. (1995). "Melia toosendan Sieb. \& Zucc". Weinheim: VCH.

Chiu, S. F. (1989). Recent advances in research on botanical insecticides in China. Insecticides Plant Orig. 387, 69-77. doi: 10.1021/bk-1989-0387.ch006

Christeller, J., Laing, W., Markwick, N., and Burgess, E. (1992). Midgut protease activities in 12 phytophagous lepidopteran larvae: dietary and protease inhibitor interactions. Insect Biochem. Molec. Biol. 22, 735-746. doi: 10.1016/09651748(92)90052-G

Cobbinah, J. R., and Osei-Owusu, K. (1988). Effects of neem seed extracts on insect pests of eggplant, okra and cowpea. Insect Sci. Appl. 9, 601-607. doi: 10.1017/ S1742758400005075

Connolly, J. (1983). "Chemistry of the limonoids of the Meliaceae and Cneoraceae," in Chemistry and Chemical Taxonomy of the Rutales, eds P. G. Waterman and M. F. Grunden (London: Academic Press), 175-213.

Da Silva, M. N., Arruda, M. S. P., Castro, K. C. F., Da Silva, M. F. D. G., Fernandes, J. B., and Vieira, P. C. (2008). Limonoids of the phragmalin type from Swietenia macrophylla and their chemotaxonomic significance. J. Nat. Prod. 71, 1983-1987. doi: 10.1021/np800312h

Day, M., and Powning, R. (1949). A study of the processes of digestion in certain insects. Australian J. Biol. Sci. 2, 175-215.

De Sousa, M. E. C., Wanderley-Teixeira, V., Teixeira, Á. A., De Siqueira, H. A., Santos, F. A., and Alves, L. C. (2009). Ultrastructure of the Alabama argillacea (Hübner) (Lepidoptera: Noctuidae) midgut. Micron 40, 743-749. doi: 10.1016/j.micron.2009.04.008

Deshmukh, C., Mohite, A., and Shinde, J. (2009). Effects of carbaryl and gamma$\mathrm{BHC}$ on the histology of midgut and digestive enzyme profiles in the third instar larvae of fruit-sucking moth, Othreis materna (Linn.) (Lepidoptera: Noctuidae). Turkish J. Zool. 33, 207-213. doi: 10.3906/zoo-0805-23

Devakumar, C., and Sukhdev. (1993). "Chemistry," in Neem Research and Development, eds N. S. Randhawa and B. S. Parmar (New Delhi: Society of Pesticide Science), 63-96.

Devakumar, C., and Kumar, R. (2008). Total synthesis of azadirachtin: a chemical odyssey. Curr. Sci. 95, 573-575.

Diamantino, T. C., Almeida, E., Soares, A. V. M. V., and Guilhermino, L. (2001). Lactate dehydrogenase activity as an effect criterion in toxicity tests with Daphnia magna straus. Chemosphere 45, 553-560. doi: 10.1016/S0045-6535(01) 00029-7

Dilawari, V., Singh, K., and Dhaliwal, G. (1994). Effects of Melia azedarach L. on oviposition and feeding of Plutella xylostella L. Insect Sci. Appl. 15, 203-206.

Dowd, P. F., Michael Smith, C., and Sparks, T. C. (1983). Detoxification of plant toxins by insects. Insect Biochem. 13, 453-468. doi: 10.1016/0020-1790(83) 90002-1

Duffey, S. S., and Stout, M. J. (1996). Antinutritive and toxic components of plant defense against insects. Arch. Insect Biochem. Physiol. 32, 3-37. doi: 10.1002/(SICI) 1520-6327(1996)32:1<3::AID-ARCH2>3.0.co:2-1

Dunn, P. E. (1986). Biochemical aspects of insect immunology. Annu. Rev. Entomol. 31, 321-339. doi: 10.1146/annurev.en.31.010186.001541

Endo, Y., and Nishiitsutsuji-Uwo, J. (1980). Mode of action of Bacillus thuringiensis $\delta$-endotoxin: histopathological changes in the silkworm midgut. J. Invert. Pathol. 36, 90-103. doi: 10.1016/0022-2011(80)90140-8

Feng, R., Chen, W., and Isman, M. B. (1995). Synergism of malathion and inhibition of midgut esterase activities by an extract from Melia toosendan (Meliaceae). Pestic. Biochem. Physiol. 53, 34-41. doi: 10.1006/pest.1995.1052

Ferreira, C., Ribeiro, A. F., Garcia, E. S., and Terra, W. R. (1988). Digestive enzymes trapped between and associated with the double plasma membranes of Rhodnius prolixus posterior midgut cells. Insect Biochem. 18, 521-530. doi: 10.1016/0020-1790(88)90003-0

Fogg, K., Anstee, J., and Hyde, D. (1991). Studies on the subcellular distribution of $\left(\mathrm{Na}^{++} \mathrm{K}^{+}\right)$-ATPase, $\mathrm{K}^{+}$-stimulated ATPase and $\mathrm{HCO}_{3}(-)$-stimulated ATPase activities in Malpighian tubules of Locusta migratoria L. Insect Biochem. 21, 749-758.

Gajmer, T., Singh, R., Saini, R., and Kalidhar, S. (2002). Effect of methanolic extracts of neem (Azadirachta indica A. Juss) and bakain (Melia azedarach L) seeds on oviposition and egg hatching of Earias vittella (Fab.) (Lep., Noctuidae). J. Appl. Entomol. 126, 238-243. doi: 10.1046/j.1439-0418.2002.00649.x

Garcia, E. D. S., and Garcia, M. L. M. (1977). Control of protease secretion in the intestine of fifth instar larvae of Rhodnius prolixus. J. Insect Physiol. 23, 247-251. doi: 10.1016/0022-1910(77)90038-5

Garcia, E., Luz, N., Azambuja, P., and Rembold, H. (1990). Azadirachtin depresses the release of prothoracicotropic hormone in Rhodnius prolixus larvae: evidence from head transplantations. J. Insect Physiol. 36, 679-682. doi: 10.1016/00221910(90)90073-O

Gebre-Amlak, A., and Azerefegne, F. (1999). Insecticidal activity of chinaberry, endod and pepper tree against the maize stalk borer (Lepidoptera: Noctuidae) in Southern Ethiopia. Int. J. Pest Manag. 45, 9-13. doi: 10.1080/096708799227987

Genta, F. A., Blanes, L., Cristofoletti, P. T., Do Lago, C. L., Terra, W. R., and Ferreira, C. (2006). Purification, characterization and molecular cloning of the major chitinase from Tenebrio molitor larval midgut. Insect Biochem. Molec. Biol. 36, 789-800. doi: 10.1016/j.ibmb.2006.07.007

George, J., and Potter, D. A. (2008). "Potential of azadirachtin for managing black cutworms and Japanese beetle grubs in turf," in II International Conference on Turfgrass Science and Management for Sports Fields (Beijing), 783, 499-506.

Haasler, C. (1984). "Effects of neem seed extract on the post-embryonic development of the tobacco hornworm, Manduca sexta," in Proceedings of the Second International Neem Conference, (Rauischholzhausen), 321-330.

Harborne, J. B. (1993). Introduction to Ecological Biochemistry. London: Elsevier Academic Press.

Harrison, H., Hodder, O., Bevan, C., Taylor, D., and Halsall, T. (1970). Crystallographic structure determination of utilin, $\mathrm{C}_{41} \mathrm{H}_{52} \mathrm{O}_{17}$, a complex meliacin with a 1, 29-cycloswietenan skeleton. J. Chem. Soc. D Chem. Commu. 1388-1389.

Hasheminia, S. M., Sendi, J. J., Jahromi, K. T., and Moharramipour, S. (2011). The effects of Artemisia annua L. and Achillea millefolium L. crude leaf extracts on the toxicity, development, feeding efficiency and chemical activities of small cabbage Pieris rapae L.(Lepidoptera: Pieridae). Pestic. Biochem. Physiol. 99, 244-249. doi: 10.1016/j.pestbp.2010.12.009

Horie, B. (1958). The alkaline phosphatase in the midgut of silkworm, Bombyx morio L. Bull. Seric. Exp. Stn. 15, 275-289.

Houseman, J. G., and Downe, A. (1980). Endoproteinase activity in the posterior midgut of Rhodnius prolixus Stål (Hemiptera: Reduviidae). Insect Biochem. 10, 363-366. doi: 10.1016/0020-1790(80)90004-9

Howard, F. (1990). Population suppression of mahogany webworm, Macalla thyrsisalis (Lepidoptera: Pyralidae), with natural products. Fla. Entomol. 225-229. doi: 10.2307/3494804

Huang, Z., Shi, P., Dai, J., and Du, J. (2004). Protein metabolism in Spodoptera litura (F.) is influenced by the botanical insecticide azadirachtin. Pestic. Biochem. Physiol. 80, 85-93. doi: 10.1016/j.pestbp.2004.07.001

Huber, R., and Mathison, R. (1976). Physical, chemical, and enzymatic studies on the major sucrase of honey bees (Apis mellifera). Can. J. Biochem. 54, 153-164. doi: 10.1139/o76-023

Isman, M. B. (1995). "Leads and prospects for the development of new botanical insecticides," in Reviews in Pesticide Toxicology, Vol. 3. eds R. M. Roe and R. J. Kuhr (Raleigh, NC: Toxicology Communications Inc.), 1-20.

Isman, M. B. (2005). Chapter Six Tropical forests as sources of natural insecticides. Recent Adv. Phytochem. 39, 145-161. doi: 10.1016/S0079-9920(05)80007-3

Isman, M. B., Koul, O., Luczynski, A., and Kaminski, J. (1990). Insecticidal and antifeedant bioactivities of neem oils and their relationship to azadirachtin content. J. Agric. Food Chem. 38, 1406-1411. doi: 10.1021/jf00096a024

Jeyasankar, A., and Jesudasan, R. W. A. (2005). Insecticidal properties of novel botanicals against a few lepidopteran pests. Pestology 29, 42-44.

Jimenez, A., Hernandez, J. A., Del Río, L. A., and Sevilla, F. (1997a). Evidence for the presence of the ascorbate-glutathione cycle in mitochondria and peroxisomes of pea leaves. Plan. Physiol. 114, 275-284.

Jimenez, A., Mata, R., Pereda-Miranda, R., Calderon, J., Isman, M., Nicol, R., et al. (1997b). Insecticidal limonoids from Swietenia humilis and Cedrela salvadorensis. J. Chem. Ecol. 23, 1225-1234. doi: 10.1023/B:JOEC.0000006460.25281.9d

Jimenez, A., Villarreal, C., Toscano, R. A., Cook, M., Arnason, J. T., Bye, R., et al. (1998). Limonoids from Swietenia humilis and Guarea grandiflora 
(Meliaceae) Taken in part from the PhD and MS theses of C. Villarreal and M. A Jiménez, respectively. Phytochemistry 49, 1981-1988. doi: 10.1016/S00319422(98)00364-1

Juan, A., Sans, A., and Riba, M. (2000). Antifeedant activity of fruit and seed extracts of Melia azedarach and Azadirachta indica on larvae of Sesamia nonagrioides. Phytoparasitica 28, 311-319. doi: 10.1007/BF02981826

Kadota, S., Marpaung, L., Kikuchi, T., and Ekimoto, H. (1990). Constituents of the seeds of Swietenia mahagoni Jacq. II. Structures of swietemahonin A, B, C, $D, E, F$, and $G$ and swietemahonolide. Chem. Pharm. Bull. 38, 894-901. doi: $10.1248 /$ cpb.38.894

Kaplan, L. A., and Pesce, A. J. (1996). Clinical Chemistry - Theory Analysis and Correlation. St. Louis, MO: Mosby-Year Book.

Katti, G., Saxena, H., and Sachan, J. N. (1992). Evaluation of antifeedant property of neem product against gram podborer, Helicoverpa armigera (Hubner). Neem Newsletter 9, 41-42.

Klocke, J. A. (1989). Plant compounds as source and models of insect-control agents. Econ. Med. Plant Res. 3, 103-144. doi: 10.1016/B978-0-12-730064$1.50009-4$

Koul, O. (1987). Antifeedant and growth inhibitory effects of calamus oil and neem oil on Spodoptera litura under laboratory conditions. Phytoparasitica 15, 169-180. doi: 10.1007/BF02979580

Koul, O., Daniewski, W. M., Multani, J. S., Gumulka, M., and Singh, G. (2003). Antifeedant effects of the limonoids from Entandrophragma candolei (Meliaceae) on the gram pod borer, Helicoverpa armigera (Lepidoptera: Noctuidae). J. Agric. Food Chem. 51, 7271-7275. doi: 10.1021/jf0304223

Koul, O., and Isman, M. B. (1991). Effects of azadirachtin on the dietary utilization and development of the variegated cutworm Peridroma saucia. J.Insect Physiol. 37, 591-598. doi: 10.1016/0022-1910(91)90036-Y

Koul, O., Jain, M., and Sharma, V. (2000). Growth inhibitory and antifeedant activity of extracts from Melia dubia to Spodoptera litura and Helicoverpa armigera larvae. Indian J. Exp. Biol. 38, 63-68.

Koul, O., Shankar, J., and Kapil, R. (1996). The effect of neem allelochemicals on nutritional physiology of larval Spodoptera litura. Entomol. Exp. Appl. 79, 43-50. doi: 10.1111/j.1570-7458.1996.tb00807.x

Koul, O., Singh, G., Singh, R., and Multani, J. (2005). Bioefficacy and mode-of-action of aglaroxin A from Aglaia elaeagnoidea (syn. A. roxburghiana) against Helicoverpa armigera and Spodoptera litura. Entomol. Exp. Appl. 114, 197-204. doi: 10.1111/j.1570-7458.2005.00259.x

Koul, O., Singh, G., Singh, R., Singh, J., Daniewski, W., and Berlozecki, S. (2004). Bioefficacy and mode-of-action of some limonoids of salannin group from Azadirachta indica A. Juss and their role in a multicomponent system against lepidopteran larvae. J. Biosci. 29, 409-416. doi: 10.1007/BF02712112

Kramer, K. J., and Koga, D. (1986). Insect chitin: physical state, synthesis, degradation and metabolic regulation. Insect Biochem. 16, 851-877. doi: 10.1016/00201790(86)90059-4

Kraus, W. (1986). Constituents of neem and related species. A revised structure of azadirachtin. Stud. Org. Chem. 26, 237-256.

Kraus, W., Bokel, M., Klenk, A., and Pöhn, H. (1985). The structure of azadirachtin and 22, 23-dihydro-23- $\beta$-methoxyazadirachtin. Tetrahedron lett. 26, 6435-6438. doi: 10.1016/S0040-4039(00)99020-8

Kraus, W., and Grimminger, W. (1981). Toonafolin, ein neues Tetranortriterpenoid-B-lacton aus Toona ciliata MJ Roem. var. australis (Meliaceae). Liebigs Ann. Chem. 1838-1843. doi: 10.1002/jlac.198119811011

Krishna-Kumari, G., Aravind, S., Balachandran, J., Ganesh, M., Soundarya Devi, S., Rajan, S., et al. (2003). Antifeedant neo- clerodanes from Teucrium tomentosum Heyne.(Labiatae). Phytochemistry 64, 1119-1123. doi: 10.1016/S00319422(03)00510-7

Kroschel, J., and Koch, W. (1996). Studies on the use of chemicals, botanicals and Bacillus thuringiensis in the management of the potato tuber moth in potato stores. Crop Prot. 15, 197-203. doi: 10.1016/0261-2194(95)00126-3

Kubo, I., and Klocke, J. (1982a). An insect growth inhibitor from Trichilia roka (Meliaceae). Experientia 38, 639-640. doi: 10.1007/BF01964065

Kubo, I., and Klocke, J. A. (1982b). Azadirachtin, insect ecdysis inhibitor. Agric. Biol. Chem. 46, 1951-1953. doi: 10.1271/bbb1961.46.1951

Leatemia, J. A., and Isman, M. B. (2004). Insecticidal activity of crude seed extracts of Annona spp., Lansium domesticum and Sandoricum koetjape against lepidopteran larvae. Phytoparasitica 32, 30-37. doi: 10.1007/BF02980856

Lechleitner, R., and Phillips, J. (1988). Anion-stimulated ATPase in locust rectal epithelium. Can. J. Zool. 66, 431-438. doi: 10.1139/z88-062
Lee, S. M., Klocke, J. A., Barnby, M. A., Yamasaki, R. B., and Balandrin, M. F. (1991). Insecticidal constituents of Azadirachta indica and Melia azedarach (Meliaceae). Nat. Occurr. Pest Bioregulators 449, 293-304. doi: 10.1021/bk-1991-0449. ch019

Lee, S. M., Olsen, J. I., Schweizer, M. P., and Klocke, J. A. (1988). 7-Deacetyl$17 \beta$-hydroxyazadiradione, a new limonoid insect growth inhibitor from Azadirachta indica. Phytochemistry 27, 2773-2775. doi: 10.1016/0031-9422(88) 80661-7

Lehane, M., Blakemore, D., Williams, S., and Moffatt, M. (1995). Regulation of digestive enzyme levels in insects. Comp. Biochem. Physiol. B Biochem. Mol. Biol. 110, 285-289. doi: 10.1016/0305-0491(94)00157-P

Levy, S. M., Falleiros, Â. M., Moscardi, F., Gregório, E. A., and Toledo, L. A. (2004). Morphological study of the hindgut in larvae of Anticarsia gemmatalis Hübner (Lepidoptera: Noctuidae). Neotrop. Entomol. 33, 427-431. doi: 10.1590/S1519566X2004000400005

Ley, S., Denholm, A., and Wood, A. (1993). The chemistry of azadirachtin. Nat. Prod. Rep. 10, 109-157. doi: 10.1039/np9931000109

Ley, S. V. (2005). Development of methods suitable for natural product synthesis: the azadirachtin story. Pure Appl. Chem. 77, 1115-1130. doi: 10.1351/pac20 0577071115

Macleod, J. K., Moeller, P. D., Molinski, T. F., and Koul, O. (1990). Antifeedant activity against Spodoptera litura larvae and [13C] NMR spectral assignments of the meliatoxins. J. Chem. Ecol. 16, 2511-2518. doi: 10.1007/BF01017474

Malczewska, M., Gelman, D., and Cymborowski, B. (1988). Effect of azadirachtin on development, juvenile hormone and ecdysteroid titres in chilled Galleria mellonella larvae. J. Insect. Physiol. 34, 725-732. doi: 10.1016/0022-1910(88) 90084-4

Martin, M. M., Jones, C., and Bernays, E. (1991). The evolution of cellulose digestion in insects [and Discussion]. Philos. Trans. R. Soc. Lond. B Biol. Sci. 333, 281-288. doi: 10.1098/rstb.1991.0078

Martinez, S., and Van Emden, H. (1999). Sublethal concentrations of azadirachtin affect food intake, conversion efficiency and feeding behaviour of Spodoptera littoralis (Lepidoptera: Noctuidae). Bull. Entomol. Res. 89, 65-71. doi: 10.1017/S0007485399000085

Matos, A. P., Leite, A. C., Batista-Pereira, L. G., Vieira, P. C., Fernandes, J. B., and Da Silva, M. (2009). Effects of limonoids from Cipadessa fruticosa on fall armyworm. Z. Naturforsch. C 64, 441.

Meisner, J., Ascher, K., Aly, R., and Warthen, J. (1981). Response of Spodoptera littoralis (Boisd.) and Earias insulana (Boisd.) larvae to azadirachtin and salannin. Phytoparasitica 9, 27-32. doi: 10.1007/BF03158326

Meisner, J., Kehat, M., Zur, M., and Eizick, C. (1978). Response of Tearias Insulana boisd. larvae to neem (Azadirachta Indica a. juss) Kernel extract. Phytoparasitica 6, 85-88. doi: 10.1007/BF02980387

Meisner, J., Wysoki, M., and Ascher, K. (1976). The residual effect of some products from Neem (Azadirachta indica A. Juss) seeds upon larvae of Boarmia (Ascotis) selenaria Schiff. in laboratory trials. Phytoparasitica 4, 185-192. doi: 10.1007/BF02981085

Miao, Y. G. (2002). Studies on the activity of the alkaline phosphatase in the midgut of infected silkworm, Bombyx mori L. J. Appl. Entomol. 126, 138-142. doi: 10.1046/j.1439-0418.2002.00625.x

Mikolajczak, K., and Reed, D. (1987). Extractives of seeds of the meliaceae: effects on Spodoptera frugiperda (JE Smith), Acalymma vittatum (F.), and Artemia salina Leach. J. Chem. Ecol. 13, 99-111. doi: 10.1007/BF01020354

Mikolajczak, K., Zilkowski, B., and Bartelt, R. (1989). Effect of meliaceous seed extracts on growth and survival of Spodoptera frugiperda (JE Smith). J. Chem. Ecol. 15, 121-128. doi: 10.1007/BF02027778

Mitchell, M., Smith, S., Johnson, S., and Morgan, E. (1997). Effects of the neem tree compounds azadirachtin, salannin, nimbin, and 6-desacetylnimbin on ecdysone 20-monooxygenase activity. Arch. Insect Biochem. Physiol. 35, 199-209. doi: 10.1002/(SICI1520)-6327(1997)35:1/2<199::AIDARCH18>3.0. co:2-6

Mordue, A. (2004). "Present concepts of the mode of action of azadirachtin from neem," in Neem: Today and in the New Millennium, ed K. W. Opender (Dordrecht: Kluwer Academic Publishers), 229-242.

Mordue, A. J., and Blackwell, A. (1993). Azadirachtin: an update. J. Insect Physiol. 39, 903-924. doi: 10.1016/0022-1910(93)90001-8

Nakatani, M. (1999). "Insect antifeeding limonoids from the chinaberry tree Melia azedarach Linn. and related compounds," in Biology-chemistry interface: $a$ tribute to Koji Nakanishi Marcel Dekker, (New York, NY), 1-22. 
Nakatani, M., Abdelgaleil, S. A., Saad, M. M., Huang, R. C., Doe, M., and Iwagawa, T. (2004). Phragmalin limonoids from Chukrasia tabularis. Phytochemistry 65, 2833-2841. doi: 10.1016/j.phytochem.2004.08.010

Nasiruddin, M., and Mordue Luntz, A. J. (1993). The effect of azadirachtin on the midgut histology of the locusts, Schistocerca gregaria and Locusta migratoria. Tissue Cell 25, 875-884. doi: 10.1016/0040-8166(93)90036-K

Nicolaou, K., Follmann, M., Roecker, A., and Hunt, K. W. (2002). Model studies towards azadirachtin: part 1. construction of the crowded C8-C14 bond by radical chemistry. Angew. Chem. Int. Ed. 41, 2103-2106. doi: 10.1002/15213773(20020167)41:12<2103::AID-ANIE2103>3.0.co:2-5

Nisbet, A. J. (2000). Azadirachtin from the neem tree Azadirachta indica: its action against insects. An. Soc. Entomol. Brasil 29, 615-632. doi: 10.1590/S030180592000000400001

Niven, M. L., and Taylor, D. A. (1988). Revision of the structure of the limonoid pseudrelone B from Pseudocedrela kotschyii. Phytochemistry 27, 1542. doi: 10.1016/0031-9422(88)80237-1

Ntalli, N. G., and Menkissoglu-Spiroudi, U. (2011). Pesticides of Botanical Origin: $a$ Promising Tool in Plant Protection. Pesticides-formulations, effects, fate. (Rijeka: InTech Europe). doi: 10.5772/13776

Ortego, F., López-Olguı ìN, J., Ruı ì, M., and Castañera, P. (1999). Effects of toxic and deterrent terpenoids on digestive protease and detoxication enzyme activities of Colorado potato beetle larvae. Pestic. Biochem. Physiol. 63, 76-84. doi: 10.1006/pest.1998.2386

Pathak, P. H., and Krishna, S. S. (1986). Reproduction efficacy in Earias fabia Stoll (Lepidoptera: Noctuidae) affected by neem oil vapour. Appl. Ent. Zool. 21, 347-348.

Phillips, J., Audsley, N., Lechleitner, R., Thomson, B., Meredith, J., and Chamberlin, M. (1988). Some major transport mechanisms of insect absorptive epithelia. Comp. Biochem. Physiol. A Physiol. 90, 643-650. doi: 10.1016/03009629(88)90679-2

Pimentel, D., and Levitan, L. (1986). Pesticides: amounts applied and amounts reaching pests. Bioscience 36, 86-91. doi: 10.2307/1310108

Pinheiro, D. O., Quagio-Grassiotto, I., and Gregório, E. A. (2008). Morphological regional differences of epithelial cells along the midgut in Diatraea saccharalis Fabricius (Lepidoptera: Crambidae) larvae. Neotrop. Entomol. 37, 413-419. doi: 10.1590/S1519-566X2008000400009

Pinheiro, D. O., Silva, R. J., Quagio-Grassiotto, I., and Gregório, E. A. (2003). Morphometric study of the midgut epithelium in larvae of Diatraea saccharalis Fabricius (Lepidoptera: Pyralidae). Neotrop. Entomol. 32, 453-459. doi: 10.1590/S1519-566X2003000300012

Powell, R. G., Mikolajczak, K. L., Zilkowski, B. W., Mantus, E. K., Cherry, D., and Clardy, J. (1991). Limonoid antifeedants from seed of Sandoricum koetjape. J. Nat. Prod. 54, 241-246. doi: 10.1021/np50073a025

Prabhaker, N., Coudriet, D., Kishaba, A., and Meyerdirk, D. (1986). Laboratory evaluation of neem-seed extract against larvae of the cabbage looper and beet armyworm (Lepidoptera: Noctuidae). J. Econ. Entomol. 79, 39-41.

Qi, S. H., Wu, D. G., Chen, L., Ma, Y. B., and Luo, X. D. (2003). Insect antifeedants from Munronia henryi: structure of munroniamide. J. Agric. Food Chem. 51, 6949-6952. doi: 10.1021/jf030292y

Qi, S. H., Zhang, S., Xiao, Z. H., Huang, J. S., Wu, J., and Li, Q. X. (2004). Study on the chemical constituents of the South China Sea gorgonian Junceella juncea. Chem. Pharm. Bull. 52, 1476-1478. doi: 10.1248/cpb.52.1476

Rajab, M. S., Bentley, M. D., Alford, A. R., and Mendel, M. J. (1988). A new limonoid insect antifeedant from the fruit of Melia volkensii. J. Nat. Prod. 51, 168-171. doi: 10.1021/np50055a030

Ramachandran, R., Mukherjee, S., and Sharma, R. (1989). Effects of food deprivation and concentration of Azadirachtin on the performance of Achoea janata and Spodoptera litura on young and mature leaves of Ricinus communis. Entomol. Exp. Appl. 51, 29-35. doi: 10.1111/j.1570-7458.1989.tb01210.x

Rembold, H. (1989). Their structure and mode of action. Insecticides Plant Orig. 387, 150-163. doi: 10.1021/bk-1989-0387.ch011

Rembold, H., Forster, H., Czoppelt, C., Rao, P., and Sieber, K. (1984). "The azadirachtins, a group of insect growth regulators from the neem tree," in Natural Pesticides from the Neem Tree and Other Tropical Plants Proceedings of the Second International Neem Conference, (Rauischholzhausen), 25-28.

Rembold, H., Sharma, G., Czoppelt, C., and Schmutterer, H. (1980). Evidence of growth disruption in insects without feeding inhibition by neem seed fractions. Z. Pflanzenkr. Pflanzenschutz 87, 290-297.
Rharrabe, K., Amri, H., Bouayad, N., and Sayah, F. (2008). Effects of azadirachtin on post-embryonic development, energy reserves and $\alpha$-amylase activity of Plodia interpunctella Hübner (Lepidoptera: Pyralidae). J. Stored Prod. Res. 44, 290-294. doi: 10.1016/j.jspr.2008.03.003

Ribeiro, S., Guilhermino, L., Sousa, J., and Soares, A. (1999). Novel bioassay based on acetylcholinesterase and lactate dehydrogenase activities to evaluate the toxicity of chemicals to soil isopods. Ecotoxicol. Environ. Saf. 44, 287-293. doi: 10.1006/eesa.1999.1837

Rosenthal, G. A., and Berenbaum, M. R. (1992). Herbivores: Their Interactions with Secondary Plant Metabolites: Ecological and Evolutionary Processes. New York, NY: Academic Press.

Roy, A., and Saraf, S. (2006). Limonoids: overview of significant bioactive triterpenes distributed in plants kingdom. Biol. Pharm. Bull. 29, 191-201. doi: 10.1248/bpb.29.191

Ruscoe, C. N. (1972). Growth disruption effects of an insect antifeedant. Nature 236,159-160. doi: 10.1038/newbio236159a0

Sakharov, I. Y., Makarova, I. E., and Ermolin, G. A. (1989). Chemical modification and composition of tetrameric isozyme $\mathrm{K}$ of alkaline phosphatase from harp seal intestinal mucosa. Comp. Biochem. Physiol. Comp. Biochem. 92, 119-122. doi: 10.1016/0305-0491(89)90322-2

Salem, S. (1991). Response of cotton bollworms, Pectinophora gossypiella Saund. and Earias insulana Boisd. to seed neem kernel pure oil. Ann. Agri. Sci. Moshtohor 29, 597-607.

Santos, C. D., Ribeiro, A. F., Ferreira, C., and Terra, W. R. (1984). The larval midgut of the cassava hornworm (Erinnyis ello). Cell Tissue Res. 237, 565-574. doi: 10.1007/BF00228441

Sarria, A. L., Soares, M. S., Matos, A. P., Fernandes, J. B., Vieira, P. C., and Da Silva, M. (2011). Effect of Triterpenoids and Limonoids Isolated from Cabralea canjerana and Carapa guianensis (Meliaceae) against Spodoptera frugiperda (J.E. Smith). Z. Naturforschung. 66, 245. doi: 10.5560/ZNC.2011.66c0245

Satasook, C., Isman, M., Ishibashi, F., Medbury, S., Wiriyachitra, P., and Towers, G. (1994). Insecticidal bioactivity of crude extracts of Aglaia species (meliaceae). Biochem. Syst. Ecol. 22, 121-127. doi: 10.1016/0305-1978(94)90002-7

Satasook, C., Isman, M. B., and Wiriyachitra, P. (1992). Activity of rocaglamide, an insecticidal natural product, against the variegated cutworm, Peridroma saucia (Lepidoptera: Noctuidae). Pestic. Sci. 36, 53-58. doi: 10.1002/ps.2780360109

Schlüter, U., Bidmon, H., and Grewe, S. (1985). Azadirachtin affects growth and endocrine events in larvae of the tobacco hornworm, Manduca sexta. J. Insect Physiol. 31, 773-777. doi: 10.1016/0022-1910(85)90070-8

Schmidt, G., Ahmed, A. A., and Breuer, M. (1997). Effect of Melia azedarach extract on larval development and reproduction parameters of Spodoptera littoralis (Boisd.) and Agrotis ipsilon (Hufn.) (lep. noctuidae). Anzeiger für Schädlingskunde, Pflanzenschutz, Umweltschutz 70, 4-12. doi: 10.1007/BF02009609

Schmidt, G., Rembold, H., Ahmed, A. A., and Breuer, M. (1998). Effect of Melia azedarach fruit extract on juvenile hormone titer and protein content in the hemolymph of two species of noctuid lepidopteran larvae (insecta: Lepidoptera: Noctuidae). Phytoparasitica 26, 283-291. doi: 10.1007/BF02981442

Schmutterer, H. (1990). Properties and potential of natural pesticides from the neem tree, Azadirachta indica. Annu. Rev. Entomol. 35, 271-297. doi: 10.1146/annurev.en.35.010190.001415

Schmutterer, H., Saxena, R., and Heyde, J. V. (1983). Morphogenetic effects of some partially-purified fractions and methanolic extracts of neem seeds on Mythimna separata (Walker) and Cnaphalocrocis medinalis (Guenée). Z. Angew. Entomol. 95, 230-237. doi: 10.1111/j.1439-0418.1983.tb02637.x

Searle, S. R. (1977). Linear Models. New York, NY: Wiley.

Senthil-Nathan, S., Choi, M. Y., Paik, C. H., Seo, H. Y., and Kalaivani, K. (2009). Toxicity and physiological effects of neem pesticides applied to rice on the Nilaparvata lugens Stal, the brown planthopper. Ecotoxicol. Environ. Saf. 72, 1707-1713. doi: 10.1016/j.ecoenv.2009.04.024

Senthil-Nathan, S., Choi, M. Y., Paik, C. H., and Seo, H. Y. (2007). Food consumption, utilization, and detoxification enzyme activity of the rice leaffolder larvae after treatment with Dysoxylum triterpenes. Pestic. Biochem. Physiol. 88, 260-267. doi: 10.1016/j.pestbp.2006.12.004

Senthil-Nathan, S. S. (2006). Effects of Melia azedarach on nutritional physiology and enzyme activities of the rice leaffolder Cnaphalocrocis medinalis (Guenée) (Lepidoptera: Pyralidae). Pestic. Biochem. Physiol. 84, 98-108. doi: 10.1016/j.pestbp.2005.05.006 
Senthil-Nathan, S., and Kalaivani, K. (2006). Combined effects of azadirachtin and nucleopolyhedrovirus (SpltNPV) on Spodoptera litura Fabricius (Lepidoptera: Noctuidae) larvae. Biol. Control 36, 94-104. doi: 10.1016/j.biocontrol.2006. 06.013

Senthil-Nathan, S., and Sehoon, K. (2006). Effects of Melia azedarach L. extract on the teak defoliator Hyblaea puera Cramer (Lepidoptera: Hyblaeidae). Crop Prot. 25, 287-291. doi: 10.1016/j.cropro.2005.03.023

Senthil-Nathan, S., Kalaivani, K., Chung, P. G., and Murugan, K. (2006a). Effect of neem limonoids on lactate dehydrogenase (LDH) of the rice leaffolder, Cnaphalocrocis medinalis (Guenee) (Insecta: Lepidoptera: Pyralidae). Chemosphere 62, 1388-1393. doi: 10.1016/j.chemosphere.2005.07.009

Senthil-Nathan, S., Kalaivani, K., Chung, K., and Murugan, K. (2006b).The toxicity and behavioural effects of neem limonoids on Cnaphalocrocis medinalis (Guenée) the rice leaffolder. Chemosphere 62, 1381-1387. doi: 10.1016/j.chemos phere.2005.07.051

Senthil-Nathan, S., Chung, P.G., and Murugan, K. (2006c). Combined effect of biopesticides on the digestive enzymatic profiles of Cnaphalocrocis medinalis (Guenée) (Rice leaffolder) (Insecta: Lepidoptera: Pyralidae) Ecotoxicol. Environ. Saf. 64, 382-389. doi: 10.1016/j.ecoenv.2005.04.008

Senthil-Nathan, S., Kalaivani, K., and Murugan, K. (2006d). Behavioural responses and changes in biology of rice leaffolder following treatment with a combination of bacterial toxin and botanical pesticides. Chemosphere 64, 1650-1658. doi: 10.1016/j.chemosphere.2006.01.037

Senthil-Nathan, S., Kalaivani, K., Chung, P.G., and Murugan, K. (2006e). Effect of biopesticides on the lactate dehydrogenase (LDH) of the rice leaffolder, Cnaphalocrocis medinalis (Guenée) (Insecta: Lepidoptera: Pyralidae). Ecotoxicol. Environ. Saf. 65, 102-107. doi: 10.1016/j.ecoenv.2005.05.021

Senthil-Nathan, S., and Kalaivani, K. (2005). Efficacy of nucleopolyhedrovirus (NPV) and azadirachtin on Spodoptera litura Fabricius (Lepidoptera: Noctuidae). Biol. Control 34, 93-98. doi: 10.1016/j.biocontrol.2005.03.001

Senthil-Nathan, S., Kalaivani, K., and Chung, P. (2005a). The effects of azadirachtin and nucleopolyhedrovirus on midgut enzymatic profile of Spodoptera litura Fab.(Lepidoptera: Noctuidae). Pestic. Biochem. Physiol. 83, 46-57. doi: 10.1016/ j.pestbp.2005.03.009

Senthil-Nathan, S., Kalaivani, K., Murugan, K., and Chung, P. G. (2005b). The toxicity and physiological effect of neem limonoids on Cnaphalocrocis medinalis (Guenée) the rice leaffolder. Pestic. Biochem. Physiol. 81, 113-122. doi: 10.1016/j.pestbp.2004.10.004

Senthil-Nathan, S., Chung, P.G., and Murugan, K. (2005c). Effect of biopesticides applied separately or together on nutritional indices of the rice leaffolder Cnaphalocrocis medinalis (Guenée) (Lepidoptera: Pyralidae). Phytoparasitica 33, 187-195. doi: 10.1007/BF03029978

Senthil-Nathan, S., Kalaivani, K., Murugan, K., and Chung, P.G. (2005d). Efficacy of neem limonoids on Cnaphalocrocis medinalis (Guenée) (Lepidoptera: Pyralidae) the rice leaffolder. Crop Prot. 24, 760-763. doi: 10.1016/j.cropro.2005. 01.009

Senthil-Nathan, S., Chung, P. G., and Murugan, K. (2004). Effect of botanical insecticides and bacterial toxins on the gut enzyme of the rice leaffolder Cnaphalocrocis medinalis. Phytoparasitica 32, 433-443. doi: 10.1007/BF02980437

Shaw, E., Mares-Guia, M., and Cohen, W. (1965). Evidence for an active-center histidine in trypsin through use of a specific reagent, 1-Chloro-3-tosylamido-7amino-2-heptanone, the chloromethyl ketone derived from $\mathrm{N} \alpha$-Tosyl-L-lysine* Biochemistry 4, 2219-2224. doi: 10.1021/bi00886a039

Shekari, M., Sendi, J. J., Etebari, K., Zibaee, A., and Shadparvar, A. (2008). Effects of Artemisia annua L.(Asteracea) on nutritional physiology and enzyme activities of elm leaf beetle, Xanthogaleruca luteola Mull.(Coleoptera: Chrysomellidae). Pestic. Biochem. Physiol. 91, 66-74. doi: 10.1016/j.pestbp.2008.01.003

Shimizu, T. (1988). Suppressive effects of azadirachtin on spermiogenesis of the diapausing cabbage armyworm, Mamestra brassicae, in vitro. Entomol. Exp. Appl. 46, 197-199. doi: 10.1111/j.1570-7458.1988.tb01111.x

Simmonds, M., and Blaney, W. (1996). Azadirachtin:-advances in understanding its activity as an antifeedant. Entomol. Exp. Appl. 80, 23-26. doi: 10.1111/j.15707458.1996.tb00877.x

Simmonds, M.S., and Blaney, W. (1984). "Some neurophysiological effects of azadirachtin on lepidopterous larvae and their feeding response," in Proceedings of the Second International Neem Conference (Rauischholzhausen), 163-180.
Slansky, F. (1985). Food utilization by insects: interpretation of observed differences between dry weight and energy efficiencies. Entomol. Exp. Appl. 39, 47-60. doi: 10.1111/j.1570-7458.1985.tb03542.x

Slansky, F., and Scriber, J. (1985). Food consumption and utilization. Comp. Insect Physiol. Biochem. Pharmacol. 4, 87-163.

Slansky, F. J. (1993). "Nutritional ecology: the fundamental quest for nutrients," in Caterpillars: Ecological and Evolutionary Constraints on Foraging, eds N. E. Stamp and T. M. Casey (New York, NY: Chapman and Hall), 29-91.

Smirle, M. J., Lowery, D. T., and Zurowski, C. L. (1996). Influence of neem oil on detoxication enzyme activity in the obliquebanded leafroller, Choristoneura rosaceana. Pestic. Biochem. Physiol. 56, 220-230. doi: 10.1006/pest.1996.0075

Sojitra, I. R., and Patel, J. R. (1992). Effect of plant extract on ovipositional behaviour of spotted bollworm, E. vittella infesting okra (Hibiscus esculentus). Indian J. Agric. Sci. 62, 848-849.

Soto, F., Hilje, L., Mora, G. A., Aguilar, M. E., and Carballo, M. (2007). Systemic activity of plant extracts in Cedrela odorata (Meliaceae) seedlings and their biological activity on Hypsipyla grandella (Lepidoptera: Pyralidae) larvae. Agric. Forest Entomol. 9, 221-226. doi: 10.1111/j.1461-9563.2007.00338.x

Srivastava, S. D. (1986). Limonoids from the seeds of Melia azedarach. J. Nat. Prod. 49, 56-61. doi: 10.1021/np50043a005

Sundaram, K. M. (1996). Azadirachtin biopesticide: a review of studies conducted on its analytical chemistry, environmental behaviour and biological effects. J. Environ. Sci. Health. B 31, 913-948. doi: 10.1080/03601239609373045

Sutherland, J. P., Baharally, V., and Permaul, D. (2002a). Use of the botanical insecticide, neem to control the small rice stinkbug Oebalus poecilus (Dallas, 1851) (Hemiptera: Pentatomidae) in Guyana. Entomotrópica 17, 97-101.

Sutherland, P., Burgess, E., Philip, B., McManus, M., Watson, L., and Christeller, J. (2002b). Ultrastructural changes to the midgut of the black field cricket (Teleogryllus commodus) following ingestion of potato protease inhibitor II. J. Insect Physiol. 48, 327-336. doi: 10.1016/S0022-1910(01)00180-9

Tan, Q. G., and Luo, X. D. (2011). Meliaceous limonoids: chemistry and biological activities. Chem. Rev. 111, 7437-7522. doi: 10.1021/cr9004023

Tanzubil, P. B., and McCaffery, A. R. (1990). Effects of azadirachtin and aqueous neem seed extracts on survival, growth and development of the African armyworm, Spodoptera exempta. Crop Prot. 9, 383-386. doi: 10.1016/02612194(90)90012-V

Teik Ng, L., Mun Yuen, P., Hong Loke, W., and Abdul Kadir, A. (2003). Effects of Azadirachta excelsa on feeding behaviour, body weight and mortality of Crocidolomia binotalis Zeller (Lepidoptera: Pyralidae). J. Sci. Food Agric. 83, 1327-1330. doi: 10.1002/jsfa.1542

Terra, W., Ferreira, C., Jordao, B., and Dillon, R. (1996). "Digestive enzymes," in Biology of the Insect Midgut, eds M. J. Lehane and P. F. Billingsley (London: Chapman and Hall), 153-186.

Terra, W. R. (1990). Evolution of digestive systems of insects. Annu. Rev. Entomol. 35, 181-200. doi: 10.1146/annurev.en.35.010190.001145

Terra, W. R. (2001). The origin and functions of the insect peritrophic membrane and peritrophic gel. Arch. Insect Biochem. Physiol. 47, 47-61. doi: 10.1002/ arch.1036

Terra, W. R., and Ferreira, C. (1994). Insect digestive enzymes: properties, compartmentalization and function. Comp. Biochem. Physiol. B Comp. Biochem. 09, 1-62. doi: 10.1016/0305-0491(94)90141-4

Thomas, A., Strunz, G., Chan, T., and Chiasson, M. (1992). Potential of Margosan-O, an azadirachtin-containing formulation from neem seed extract, as a control agent for spruce budworm, Choristoneura fumiferana. Entomol. Exp. Appl. 62, 37-46. doi: 10.1111/j.1570-7458.1992.tb00639.x

Timmins, W., and Reynolds, S. (1992). Azadirachtin inhibits secretion of trypsin in midgut of Manduca sexta caterpillars: reduced growth due to impaired protein digestion. Entomol. Exp. Appl. 63, 47-54. doi: 10.1111/j.1570-7458.1992.tb0 2418. $x$

USEPA (United States Environmental Protection Agency). (2011). Pesticide news story: EPA releases report containing latest estimates of pesticide use in the United States. Retrieved March 23, 2013.

Vanucci, C., Lange, C., Lhommet, G., Dupont, B., Davoust, D., Vauchot, B., et al. (1992). An insect antifeedant limonoid from seed of Khaya ivorensis. Phytochemistry 31, 3003-3004. doi: 10.1016/0031-9422(92)83435-2

Varma, J., and Dubey, N. (1999). Prospectives of botanical and microbial products as pesticides of tomorrow. Curr. Sci. 76, 172-178. 
Verkerk, R. H., and Wright, D. J. (1993). Biological activity of neem seed kernel extracts and synthetic azadirachtin against larvae of Plutella xylostella L. Pestic. Sci. 37, 83-91. doi: 10.1002/ps.2780370113

Waldbauer, G. (1968). The consumption and utilization of food by insects. $A d v$. Insect Physiol. 5, 229-288. doi: 10.1016/S0065-2806(08)60230-1

Weinzierl, R., and Henn, T. (1991). Alternatives in Insect Management: Biological and Biorational Approaches. Urbana, IL: North central regional extension publication.

Wheeler, D. A., and Isman, M. B. (2001). Antifeedant and toxic activity of Trichilia americana extract against the larvae of Spodoptera litura. Entomol. Exp. Appl. 98, 9-16. doi: 10.1046/j.1570-7458.2001.00751.x

Wheeler, D. A., Isman, M. B., Sanchez-Vindas, P. E., and Arnason, J. T. (2001). Screening of Costa Rican Trichilia species for biological activity against the larvae of Spodoptera litura (Lepidoptera: Noctuidae). Biochem. Syst. Ecol. 29, 347-358. doi: 10.1016/S0305-1978(00)00070-3

Wheeler, G., and Slansky, F. (1991). Compensatory responses of the fall armyworm (Spodoptera frugiperda) when fed water-and cellulose-diluted diets. Physiol. Entomol. 16, 361-374. doi: 10.1111/j.1365-3032.1991.tb00574.x

Wu, J., Xiao, Q., Zhang, S., Li, X., Xiao, Z., Ding, H., et al. (2005). Xyloccensins Q-V, six new 8, 9, 30-phragmalin ortho ester antifeedants from the Chinese mangrove Xylocarpus granatum. Tetrahedron 61, 8382-8389. doi: 10.1016/j.tet.2005. 06.099

Wu, R. S., and Lam, P. K. (1997). Glucose-6-phosphate dehydrogenase and lactate dehydrogenase in the green-lipped mussel (Perna viridis): possible biomarkers for hypoxia in the marine environment. Water Res. 31, 2797-2801. doi: 10.1016/S0043-1354(97)00116-4

Wyatt, G. (1967). The biochemistry of sugars and polysaccharides in insects. $A d v$. Insect Physiol. 4, 287-360. doi: 10.1016/S0065-2806(08)60210-6

Xie, Y., Isman, M., Gunning, P., Mackinnon, S., Arnason, J., Taylor, D., et al. (1994). Biological activity of extracts of Trichilia species and the limonoid hirtin against lepidopteran larvae. Biochem. Syst. Ecol. 22, 129-136. doi: 10.1016/03051978(94)90003-5

Yasmin, N., Naqvi, S., Khan, M., Munir, A., and Tariq, R. (2010). Role of neem product $\left(\right.$ Biosal $\left.^{\circledR}\right)$ and its impact on cholinesterase and protein contents in larvae of Papilio demoleus L. in comparison with cypermethrin. J. Exp. Zool. India $13,541-544$.
Yu, S. (1983). Induction of detoxifying enzymes by allelochemicals and host plants in the fall armyworm. Pestic. Biochem. Physiol. 19, 330-336. doi: 10.1016/00483575(83)90061-5

Zebe, E., and McShan, W. (1957). Lactic and $\alpha$-glycerophosphate dehydrogenases in insects. J. Gen. Physiol. 40, 779-790. doi: 10.1085/jgp.40.5.779

Zhang, C. R., Fan, C. Q., Zhang, L., Yang, S. P., Wu, Y., Lu, Y., et al. (2008a). Chuktabrins A and B, two novel limonoids from the twigs and leaves of Chukrasia tabularis. Org. Lett. 10, 3183-3186. doi: 10.1021/ol800885h

Zhang, H., Odeku, O. A., Wang, X. N., and Yue, J. M. (2008b). Limonoids from the stem bark of Khaya grandifoliola. Phytochemistry 69, 271-275. doi: 10.1016/j.phytochem.2007.06.009

Zibaee, A., Sendi, J. J., Etebari, K., Alinia, F., and Ghadamyari, M. (2008). The effect of diazinon on some biochemical characteristics of Chilo suppressalis Walker (Lepidoptera: Pyralidae), rice striped stem borer. Mun. Entomol. Zool. 3, 255-264.

Žitòan, D., Šauman, I., and Sehnal, F. (1993). Peptidergic innervation and endocrine cells of insect midgut. Arch. Insect Biochem. Physiol. 22, 113-132. doi: 10.1002/arch.940220110

Conflict of Interest Statement: The author declares that the research was conducted in the absence of any commercial or financial relationships that could be construed as a potential conflict of interest.

Received: 15 October 2013; accepted: 22 November 2013; published online: 20 December 2013.

Citation: Senthil-Nathan S (2013) Physiological and biochemical effect of neem and other Meliaceae plants secondary metabolites against Lepidopteran insects. Front. Physiol. 4:359. doi: 10.3389/fphys.2013.00359

This article was submitted to Invertebrate Physiology, a section of the journal Frontiers in Physiology.

Copyright (c) 2013 Senthil-Nathan. This is an open-access article distributed under the terms of the Creative Commons Attribution License (CC BY). The use, distribution or reproduction in other forums is permitted, provided the original author(s) or licensor are credited and that the original publication in this journal is cited, in accordance with accepted academic practice. No use, distribution or reproduction is permitted which does not comply with these terms. 